\title{
Preferential Inhibition of Tonically over Phasically Activated NMDA Receptors by Pregnane Derivatives
}

\author{
DVojtech Vyklicky, ${ }^{1 \star}$ Tereza Smejkalova, ${ }^{1 \star}$ Barbora Krausova, ${ }^{1}$ Ales Balik, ${ }^{1}$ Miloslav Korinek, ${ }^{1}$ Jirina Borovska, ${ }^{1}$ \\ Martin Horak, ${ }^{1}$ Marketa Chvojkova, ${ }^{1}$ Lenka Kleteckova, ${ }^{1}$ Karel Vales, ${ }^{1}$ Jiri Cerny, ${ }^{1}$ Michaela Nekardova, ${ }^{2,3}$ \\ Hana Chodounska, ${ }^{2}$ Eva Kudova, ${ }^{2}$ and Ladislav Vyklicky ${ }^{1}$ \\ ${ }^{1}$ Institute of Physiology, Czech Academy of Sciences, 14220 Prague 4, Czech Republic, ${ }^{2}$ Institute of Organic Chemistry and Biochemistry, Czech Academy of \\ Sciences, 16610 Prague 2, Czech Republic, and ${ }^{3}$ Faculty of Mathematics and Physics, Charles University in Prague, 121 16 Prague 2, Czech Republic
}

Postsynaptic $N$-methyl-D-aspartate receptors (NMDARs) phasically activated by presynaptically released glutamate are critical for synaptic transmission and plasticity. However, under pathological conditions, excessive activation of NMDARs by tonically increased ambient glutamate contributes to excitotoxicity associated with various acute and chronic neurological disorders. Here, using heterologously expressed GluN1/GluN2A and GluN1/GluN2B receptors and rat autaptic hippocampal microisland cultures, we show that pregnanolone sulfate inhibits NMDAR currents induced by a prolonged glutamate application with a higher potency than the NMDAR component of EPSCs. For synthetic pregnanolone derivatives substituted with a carboxylic acid moiety at the end of an aliphatic chain of varying length and attached to the steroid skeleton at $\mathrm{C} 3$, the difference in potency between tonic and phasic inhibition increased with the length of the residue. The steroid with the longest substituent, pregnanolone hemipimelate, had no effect on phasically activated receptors while inhibiting tonically activated receptors. In behavioral tests, pregnanolone hemipimelate showed neuroprotective activity without psychomimetic symptoms. These results provide insight into the influence of steroids on neuronal function and stress their potential use in the development of novel therapeutics with neuroprotective action.

Key words: memantine; neuroprotection; neurosteroid; NMDA receptor; pregnanolone sulfate; synaptic transmission

Significance Statement

Synaptic activation of $N$-methyl-D-aspartate receptors (NMDARs) plays a key role in synaptic plasticity, but excessive tonic NMDAR activation mediates excitotoxicity associated with many neurological disorders. Therefore, there is much interest in pharmacological agents capable of selectively blocking tonically activated NMDARs while leaving synaptically activated NMDARs intact. Here, we show that an endogenous neurosteroid pregnanolone sulfate is more potent at inhibiting tonically than synaptically activated NMDARs. Further, we report that a novel synthetic analog of pregnanolone sulfate, pregnanolone hemipimelate, inhibits tonic NMDAR currents without inhibiting the NMDAR component of the EPSC and shows neuroprotective activity in vivo without inducing psychomimetic side effects. These results suggest steroids may have a clinical advantage over other known classes of NMDAR inhibitors.

\section{Introduction}

$N$-methyl-D-aspartate receptors (NMDARs) are a subtype of ionotropic glutamate receptors that are highly permeable to cal- cium and expressed by virtually all neurons in the mammalian CNS. They are localized at a high density at postsynaptic regions, but are also present in extrasynaptic membrane (Petralia, 2012).
Received Aug. 25, 2015; revised Dec. 11, 2015; accepted Jan. 4, 2016.

Author contributions: V.V., T.S., K.V., J.C., H.C., E.K., and L.V. designed research; V.V., T.S., B.K., A.B., M.K., J.B., M.H., M.C., L.K., M.N., H.C., and E.K. performed research; V.V., T.S., B.K., A.B., M.K., J.B., M.H., M.C., L.K., K.V., J.C., M.N., H.C., E.K., and L.V. analyzed data; V.V., T.S., K.V., J.C., H.C., E.K., and L.V. wrote the paper.

This work was supported by the Czech Science Foundation (Grants 303/12/1464 and P304/12/G069), the Technology Agency of the Czech Republic (Grant TE01020028), the Grant Agency of Charles University (Grant 1520-243253483; 800313/2012/2.LF, Research Project of the CAS (Grant RV0: 67985823, the Center of Biomedical Research (CZ.1.07/2.3.00/30.0025 project supported by the European Science Foundation), Biotechnology and Biomedicine Center of the Academy of Sciences and Charles University in Vestec (CZ.1.05/1.1.00/02.0109 project supported by the European Regional Development Fund). The computational study by M.N. was supported by the (zech Science Foundation (Grant P208/12/G016) and Research Project RV0: 61388963 of the Institute of Organic Chemistry and
Biochemistry, CAS. Molecular graphics and analyses were performed with the University of California-San Francisco Chimera package, developed by the Resource for Biocomputing, Visualization, and Informatics (supported by $\mathrm{Na}$ tional Institute of General Medical Sciences Grant P41-GM103311). We thank M. Kuntosova for excellent technical assistance and Grygoryi Tsenov for fruitful consultations.

The authors hold U.S. Patent No.: US8575376: "Steroid Anionic Compounds: Method of Their Production, Usage,

and Pharmaceutical Preparation Involving Them," without direct corporate involvement at this time.

*V.V. and T.S. contributed equally to this work.

Correspondence should be addressed to Dr. Ladislav Vyklicky, Jr, Institute of Physiology CAS, Videnska 1083, 142 20 Prague 4, Czech Republic. E-mail: vyklicky@biomed.cas.cz.

DOI:10.1523/JNEUROSCI.3181-15.2016

Copyright $\odot 2016$ the authors $\quad 0270-6474 / 16 / 362161-15 \$ 15.00 / 0$ 
At excitatory synapses, glutamate is phasically released from presynaptic terminals, producing a glutamate concentration transient with an estimated peak of $\sim 1 \mathrm{~mm}$ and a decay time constant of 1-2 ms (Clements et al., 1992). Synaptically activated NMDARs are vital for synaptogenesis, synaptic plasticity, learning, and memory (Lynch, 2004; Traynelis et al., 2010; Huganir and Nicoll, 2013). Further, phasic/synaptic NMDAR activation may promote cell survival under some conditions (Hardingham et al., 2002; Léveillé et al., 2008; Papadia et al., 2008; but see Wroge et al., 2012).

Tonic NMDAR activation, conversely, mediates excitotoxicity. Glutamate transporters normally maintain glutamate concentration in the extracellular space at low levels. Estimates of the "physiological" ambient glutamate concentration vary from as low as $25 \mathrm{~nm}$ to 1-4 $\mu \mathrm{M}$ (Sah et al., 1989; Wahl et al., 1994; Cavelier et al., 2005; Herman and Jahr, 2007). Under pathological conditions, however, ambient glutamate concentration increases, resulting in tonic receptor activation that results in excitotoxicity (Olney, 1969). This form of neuronal death is dependent on calcium influx through NMDARs (Choi, 1987) and is implicated in a variety of neurological conditions (Parsons and Raymond, 2014).

Given the different outcomes of tonic versus phasic/synaptic NMDAR signaling, there is much interest in NMDAR inhibitors capable of selectively blocking tonically activated NMDARs while leaving phasically/synaptically activated NMDARs intact. Inhibitors of NMDARs have shown some promise in models of human neurodegenerative diseases (Choi and Rothman, 1990), but their broader use is limited by their side effects that typically include psychomimetic symptoms, presumably due to the inhibition of normal synaptic transmission (Lipton, 1993; Rogawski, 1993; Rogawski and Wenk, 2003; Manahan-Vaughan et al., 2008). Memantine, an NMDAR antagonist used in Alzheimer's disease therapy, has been suggested to block preferentially tonically activated extrasynaptic NMDARs rather than phasically activated synaptic NMDARs, with a 2 -fold difference in the $\mathrm{IC}_{50}$ values (Xia et al., 2010), although other studies found a smaller difference (Emnett et al., 2013). Theoretical considerations predict that, although NMDAR inhibitors with use-dependent onset and offset of inhibition ("trapping" blockers), exemplified by memantine, would show some preference for tonically versus phasically activated NMDARs, the strongest selectivity would be achieved by use-dependent inhibitors with slow onset and useindependent offset of inhibition ("foot-in-the-door" block; Vyklicky et al., 2014). Because an endogenous neurosteroid, 20oxo- $5 \beta$-pregnan- $3 \alpha$-yl sulfate (PA-S; $3 \alpha, 5 \beta$-pregnanolone sulfate), is an NMDAR inhibitor with a foot-in-the-door mechanism of block (Petrovic et al., 2005; Vyklicky et al., 2015), we have explored the effect of PA-S and novel synthetic PA-S analogs on synaptically activated NMDARs and on receptors activated by sustained glutamate applications.

The results of our experiments, in agreement with the prediction, demonstrate that PA-S has a higher preference for tonically activated NMDARs than for NMDARs activated during synaptic transmission. All of the six structural analogs of PA-S tested exhibited a higher preference for tonically activated receptors. The most selective PA-S analog, pregnanolone hemipimelate (PA-hPim), showed no inhibition of phasically and synaptically activated receptors while inhibiting tonically activated receptors. Behavioral tests demonstrate that PA-hPim has neuroprotective activity without inducing psychomimetic symptoms. Overall, our results provide a unique opportunity for the development of new therapeutic neurosteroid-based ligands to treat diseases associated with the dysfunction of the glutamate system.

\section{Materials and Methods}

\section{Cell culture}

HEK293 cells. Human embryonic kidney 293 (HEK293) cells were maintained in Opti-MEM I (Invitrogen) supplemented with 5\% fetal bovine serum (PAN Biotech) at $37^{\circ} \mathrm{C}$ in $5 \% \mathrm{CO}_{2}$. Cells were plated at a density of $10^{5}$ cells $/ \mathrm{cm}^{2}$ and $24 \mathrm{~h}$ later transiently transfected with expression vectors containing the rat glutamate receptor subunits GluN1-1a (GenBank accession no. U08261) and GluN2A (GenBank accession no. D13211) or GluN2B (GenBank accession no. M91562) using Matra-A reagent (IBA) (Borovska et al., 2012). Equal amounts $(300 \mu \mathrm{g})$ of cDNAs encoding for GluN1, GluN2A or GluN2B, and GFP (pQBI 25; Takara) were used. After trypsinization, the cells were resuspended in Opti-MEM I containing $1 \%$ fetal bovine serum supplemented with $20 \mathrm{~mm} \mathrm{MgCl}_{2}, 1 \mathrm{~mm}$ D,L-2-amino-5-phosphonopentanoic acid (D,L-AP5), and $3 \mathrm{~mm}$ kynurenic acid to prevent excitotoxicity.

Micro-island cultures. Micro-island cultures were prepared as described previously (Burgalossi et al., 2012). Glass coverslips were coated with $0.15 \%$ agarose (Serva) and stamped with an array of microdots ( $\sim 200 \mu \mathrm{m}$ in diameter, spaced $\sim 200 \mu \mathrm{m}$ apart) of permissive substrate containing $0.1 \mathrm{mg} / \mathrm{ml}$ poly-D-lysine and $0.2 \mathrm{mg} / \mathrm{ml}$ collagen (Serva). Primary cortical astrocyte cultures were prepared from postnatal day 1 male Wistar rat pups and grown for 1-2 weeks in DMEM with GlutaMax (Invitrogen), 10\% fetal bovine serum (Invitrogen) and pen/strep before being plated on the microdot-stamped coverslips at 5000 cells $/ \mathrm{cm}^{2}$. Hippocampal neurons were isolated from postnatal day 1 male Wistar rat pups and plated on top of the astrocyte microislands at $3000 \mathrm{cells} / \mathrm{cm}^{2}$ in Neurobasal A medium with B27 Supplement (Invitrogen), GlutaMax, and pen/strep. This protocol yields a large proportion of islands containing a solitary hippocampal neuron forming autapses.

\section{Electrophysiology}

HEK293 cells were used for electrophysiological recordings $24-48 \mathrm{~h}$ after transfection. Whole-cell voltage-clamp recordings were made at room temperature at a holding potential of $-60 \mathrm{mV}$, with capacitance and series resistance $(<10 \mathrm{M} \Omega)$ compensation of $80-90 \%$. Data were acquired with an Axopatch 200B amplifier, sampled at $10 \mathrm{kHz}$, and filtered at $2 \mathrm{kHz}$. Patch pipettes $(3-5 \mathrm{M} \Omega$ ) were filled with a solution containing the following (in mM): 120 gluconic acid, $15 \mathrm{CsCl}, 10$ BAPTA, 10 HEPES, $3 \mathrm{MgCl}_{2}, 1 \mathrm{CaCl}_{2}$, and 2 ATP-Mg salt, $\mathrm{pH}$ adjusted to 7.2 with $\mathrm{CsOH}$. Extracellular solution contained the following (in $\mathrm{mm}$ ): $160 \mathrm{NaCl}, 2.5$ $\mathrm{KCl}, 10 \mathrm{HEPES}, 10$ glucose, $0.2 \mathrm{EDTA}$, and $0.7 \mathrm{CaCl}_{2}$, $\mathrm{pH}$ adjusted to 7.3 with $\mathrm{NaOH}$. Glycine $(10 \mu \mathrm{M})$ was present in the control and test solutions. Drug applications were made with a microprocessor-controlled multibarrel fast perfusion system. The solution exchange rate was $\sim 10 \mathrm{~ms}$.

Whole-cell voltage-clamp recordings of autaptic EPSCs were obtained at room temperature at a holding potential of $-70 \mathrm{mV}$ from solitary excitatory hippocampal neurons at $11-16 \mathrm{~d}$ in vitro. Intracellular solution contained the following (in $\mathrm{mm}$ ): 125 gluconic acid, $15 \mathrm{KCl}, 10$ HEPES, 5 EGTA, $0.5 \mathrm{CaCl}_{2}$, 2 ATP-Mg salt, 0.3 GTP-Na salt, and 10 creatine phosphate, $\mathrm{pH}$ adjusted to 7.2 with $\mathrm{KOH}$. Autaptic EPSCs were evoked by $1 \mathrm{~ms}$ depolarization to $0 \mathrm{mV}$ every $15 \mathrm{~s}$. Evoked dual AMPA and NMDA EPSCs were recorded in extracellular solution containing the following (in mM): $160 \mathrm{NaCl}, 2.5 \mathrm{KCl}, 10$ glucose, 10 HEPES, $2 \mathrm{CaCl}_{2}$, 0.01 glycine, and 0.01 bicuculline methochloride, $\mathrm{pH}$ adjusted to 7.3 with $\mathrm{NaOH}$. To assess presynaptic effects of steroids, $50 \mu \mathrm{M}$ D-AP5 was added to the above extracellular solution to isolate AMPA EPSCs and pairedpulse stimulation with $50 \mathrm{~ms}$ interpulse interval was used to evoke a pair of EPSCs every $15 \mathrm{~s}$. To isolate AMPA mEPSCs, $0.5 \mu \mathrm{M}$ TTX was added to the extracellular solution. Solutions were applied using a gravity-fed fast perfusion system with a manifold connecting to a single solution outlet. During the recordings of evoked EPSCs (but not miniature EPSCs) series resistance $(<20 \mathrm{M} \Omega)$ was $80 \%$ compensated. Data were acquired with an Axopatch 200B amplifier, sampled at $20 \mathrm{kHz}$, filtered at $2 \mathrm{kHz}$, and analyzed with pClamp software. The AMPA component of the dual EPSC was estimated as the peak of the response. The NMDA component 
<smiles>CC[C@H]1CC[C@@]2(C)C3CC[C@]4(C)C(C(C)=O)CCC4C3CC[C@]2(C)C1</smiles><smiles></smiles>

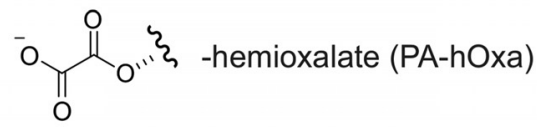

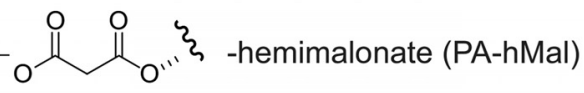

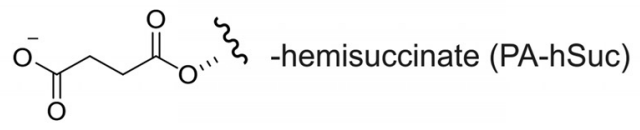

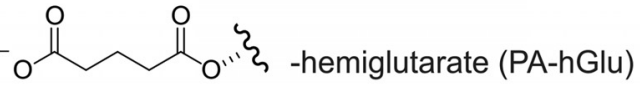

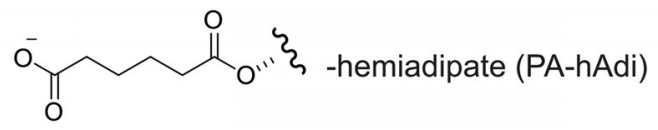

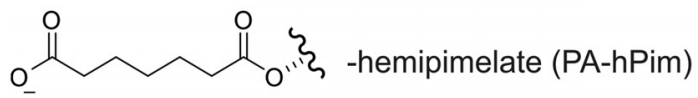

Figure 1. Chemical structures of steroids tested for their biological activity at NMDARs. The structure of PA and the residues substituted in position $\alpha$ of carbon C 3 are shown.

of the dual EPSC was estimated from the double-exponential fit to the decay of the later portion of the EPSC (starting at $40 \mathrm{~ms}$ after stimulation, after the AMPA component had decayed to baseline) and extrapolated to the expected time of NMDA EPSC peak (14 ms after stimulation, as determined from control NMDA EPSCs recorded in the presence of 10 $\mu \mathrm{M}$ CNQX).

Steroids were dissolved in DMSO and added to the extracellular solution at the indicated concentrations, with the final DMSO concentration of $1 \%$. An equivalent amount of DMSO was present in control solutions. All drugs, unless otherwise stated, were purchased from Sigma-Aldrich.

Data analysis

$\mathrm{IC}_{50}$ was determined from a fit to the following logistic equation:

$$
I=\frac{100}{1+\left(\frac{\mathrm{IC}_{50}}{[\text { steroid }]}\right)^{h}}
$$

or from a single dose of steroid using the following formula:

$$
\mathrm{IC}_{50}=[\text { steroid }] \times \sqrt[h]{\frac{100-I}{I}}
$$

Where $I$ is the relative degree of inhibition in \%, [steroid] is the steroid concentration used and $h$ fixed at 1.0 for peak and 1.2 for steady state, based on the dose-response curves for PA-S (see Fig. 2B). Calculations of $\mathrm{IC}_{50}$ were made assuming $100 \%$ inhibition at a saturating steroid concentration.

\section{Steroid synthesis}

$3 \alpha, 5 \beta$-pregnanolone (PA-OH; Steraloids) was the starting material for the preparation of the majority of the steroids studied (Fig. 1). Pyridine sulfur trioxide complex with pregnanolone afforded PA-S (Stastna et al., 2009). Then, PA-OH treated with oxalic acid dichloride gave hemioxalate (PAhOxa). Treatment by 2,2-dimethyl-1,3-dioxane-4,6-dione (Meldrum's acid) gave hemimalonate (PA-hMal). Reactions of PA-OH with succinic or glutaric anhydrides afforded-hemisuccinate (PA-hSuc; Stastna et al., 2009) and -hemiglutarate (PA-hGlu), respectively. Selective monoesterification of PA-OH with adipic or pimelic acids catalyzed by $N, N^{\prime}$-dicyclohexylcarbodiimide and $\mathrm{N}, \mathrm{N}$-dimethyl-4-aminopyridine yielded steroid-hemiadipate (PA-hAdi) and -hemipimelate (PA-hPim), respectively (see below).

Melting points $(\mathrm{Mp})$ were determined on a micro-melting point apparatus (Helmut Hund) and are uncorrected. Optical rotations were measured in chloroform using an Autopol IV (Rudolf Research Analytical). $[\alpha]_{\mathrm{D}}$ values are given in degrees $\left(10^{-1} \mathrm{deg} \mathrm{cm}^{2} \mathrm{~g}^{-1}\right)$. IR spectra were recorded on a Bruker IFS 55 spectrometer (wave numbers in $\mathrm{cm}^{-1}$ ). Proton and carbon NMR spectra were measured on an FT NMR spectrometer Bruker AVANCE-400 $(400 \mathrm{MHz}, 101 \mathrm{MHz})$ in $\mathrm{CDCl}_{3}$ with tetramethylsilane as the internal standard (unless otherwise stated). Chemical shifts are given in parts per million (delta scale). Coupling constants $(J)$ and width of multiplets $(W)$ are given in Hertz. Mass spectra were obtained with spectrometers ZAB-EQ (at $70 \mathrm{eV}$ ) or LCQ Classic (Thermo-Finnigan). Thin-layer chromatography (TLC) was performed on silica gel (ICN Biochemicals). Preparative TLC (prep-TLC) was performed on $200 \mathrm{~mm} \times 200 \mathrm{~mm}$ plates coated with a $0.4-\mathrm{mm}$-thick layer of the same material. For column chromatography, neutral silica gel $60 \mu \mathrm{m}$ (Merck) was used. Analytical samples were dried over phosphorus pentoxide at $50^{\circ} \mathrm{C} / 100 \mathrm{~Pa}$. Anhydrous THF was prepared by distillation with benzophenone/Na immediately before use.

$P A-S$. For details of PA-S preparation, please see Stastna et al. (2009). PA-hOxa. A mixture of PA-OH (320 mg, $1 \mathrm{mmol})$, dry dichloromethane $(4 \mathrm{ml})$, triethylamine $(0.14 \mathrm{ml})$, and 1 drop of previously prepared solution ( $2 \mathrm{ml}$ of dry dichloromethane and 1 drop dimethylformamide) was added to a cooled $\left(0^{\circ} \mathrm{C}\right)$ mixture of dichloromethane $(2 \mathrm{ml})$ and oxalic acid dichloride $(0.26 \mathrm{ml}, 3 \mathrm{mmol})$. The mixture was allowed to attain $10^{\circ} \mathrm{C}$ and then stirred for $2 \mathrm{~h}$ under these conditions. Then, $20 \mathrm{ml}$ of water was added to decompose excess of the reagent and the mixture was stirred for $30 \mathrm{~min}$ at room temperature. The organic layer was separated and ethyl acetate $(20 \mathrm{ml})$ was added to the dichloromethane extract. Then, aqueous solution of potassium carbonate was added $(10 \%$, $50 \mathrm{ml}$ ), the organic layer with undesired by-products was separated and, subsequently, aqueous solution of $\mathrm{HCl}(1 \mathrm{~N}$, to $\mathrm{pH} \sim 4)$ was cautiously added to the aqueous layer. The crude product was obtained by extraction with ethyl acetate $(2 \times 25 \mathrm{ml})$ and dried. Crystallization from acetone $/ n$-heptane gave $230 \mathrm{mg}$ (59\%) of hemioxalate (PA-hOxa): Mp $112-114^{\circ} \mathrm{C} .[\alpha]_{\mathrm{D}}+110\left(c 0.37, \mathrm{CHCl}_{3}\right) .{ }^{1} \mathrm{H}$ NMR: $\delta 0.60\left({ }^{3} \mathrm{H}, s, \mathrm{H}-18\right)$, $0.96\left({ }^{3} \mathrm{H}, s, \mathrm{H}-19\right), 2.14\left({ }^{3} \mathrm{H}, s, \mathrm{H}-21\right), 2.55\left({ }^{1} \mathrm{H}, t, J=8.8, \mathrm{H}-17\right), 4.96$ $\left({ }^{1} \mathrm{H}, \mathrm{m}, \mathrm{H}-3\right) .{ }^{13} \mathrm{C}$ NMR: $\delta 211.0(\mathrm{C}-20), 157.9(\mathrm{COOH}), 157.8(\mathrm{CO}-\mathrm{O})$, 79.0 (C-3), 64.0 (C-17), 56.9, 44.69, 42.0, 40.5, 39.3, 35.9, 35.0, 34.8, 31.9, 31.6, 27.0, 26.4, 26.3, 24.6, 23.3, 23.1, 21.0, 13.6. IR $\left(\mathrm{CHCl}_{3}\right): 2938,2873$, 1735, 1699, 1238, 1231, 1194. MS: ESI m/z 317.3 (100\%, M-COCOOH), 389.3 (25\%, M-1). HR-MS (ESI) $\mathrm{m} / \mathrm{z}$ for $\mathrm{C}_{23} \mathrm{H}_{33} \mathrm{O}_{5}$ [M-1] calculated 389.2334, found 389.2334.

PA-hMal. PA-OH (320 mg, $1 \mathrm{mmol}$ ) in dry toluene was added to a dry reaction vessel with 2,2-dimethyl-4,6-dioxo-1,3-dioxolane (Meldrum's acid, $160 \mathrm{mg}, 1.1 \mathrm{mmol}$ ). The reaction mixture was stirred and heated to reflux for $4 \mathrm{~h}$. Solvent was evaporated under reduced pressure. Chromatography of the crude product $(422 \mathrm{mg})$ on a small $(10 \mathrm{~g})$ silica gel column ( $10 \%$ acetone in petroleum ether) gave $230 \mathrm{mg}$ of oily product, which after crystallization (ether/petroleum ether) afforded (PA-hMal) as white crystals $190 \mathrm{mg}(47 \%): \mathrm{Mp} 118-120^{\circ} \mathrm{C} .[\alpha]_{\mathrm{D}}+116(c 0.23$, $\left.\mathrm{CHCl}_{3}\right) .{ }^{1} \mathrm{H}$ NMR: $\delta 0.60\left({ }^{3} \mathrm{H}, \mathrm{s}, \mathrm{H}-18\right), 0.95\left({ }^{3} \mathrm{H}, \mathrm{s}, \mathrm{H}-19\right), 2.11\left({ }^{3} \mathrm{H}, \mathrm{s}\right.$, $\mathrm{H}-21), 2.53\left({ }^{1} \mathrm{H}, t, J=8.8, \mathrm{H}-17\right), 3.41\left({ }^{2} \mathrm{H}, \mathrm{s}, \mathrm{H}-2^{\prime}\right), 4.84\left({ }^{1} \mathrm{H}, \mathrm{m}, \mathrm{H}-3\right)$. ${ }^{13}$ C NMR: $\delta 209.8$ (C-20), 178.0 (COOH), 173.0 (COO), $73.8(\mathrm{C}-3), 64.0$ (C-17), 56.8, 44.5, 42.0, 40.6, 39.3, 35.9, 35.1, 34.83, 32.2, 31.7, 26.9, 26.6, 26.4, 24.6, 23.4, 23.1, 21.0, 13.6. IR $\left(\mathrm{CHCl}_{3}\right): 3509,3090,2701(\mathrm{OH})$; 1735, $1700(\mathrm{C}=\mathrm{O}$, carboxyl); $1718(\mathrm{C}=\mathrm{O}, 20$-ketone $), 1194,1156(\mathrm{C}-\mathrm{O})$. MS: ESI m/z $427.2(100 \%, \mathrm{M}+\mathrm{Na})$. HR-MS (ESI) $\mathrm{m} / \mathrm{z}$ for $\mathrm{C}_{24} \mathrm{H}_{36} \mathrm{O}_{5} \mathrm{Na}$ $(\mathrm{M}+\mathrm{Na})$ calculated 427.2455, found 427.2455. For $\mathrm{C}_{24} \mathrm{H}_{36} \mathrm{O}_{5}(404.5)$ calculated: $71.26 \%$ C, $8.97 \% \mathrm{H}$; found: $71.30 \% \mathrm{C}, 9.10 \% \mathrm{H}$. As a side 
product (132 mg, 40\%) was isolated less polar dipregnanolone malonyl ester.

PA-hSuc. For details of PA-hSuc preparation, please see Stastna et al. (2009).

PA-hGlu. A mixture of PA-OH (320 mg, $1 \mathrm{mmol})$ and glutaric acid anhydride $\left(573 \mathrm{mg}, 5 \mathrm{mmol}\right.$ ) was dried overnight at $50^{\circ} \mathrm{C}$. Dry pyridine $(6 \mathrm{ml})$ and 4 -(dimethylamino)pyridine ( $184 \mathrm{mg}, 1.5 \mathrm{mmol}$ ) were added. The mixture was refluxed for $36 \mathrm{~h}$. The reaction mixture was poured into water and extracted with chloroform $(3 \times 20 \mathrm{ml})$, combined organic extracts were washed with brine and dried. Solvents were evaporated and the brown residue was purified by column chromatography (10\% of acetone in petroleum ether) to afford white solids. Crystallization from ethyl acetate/acetone/petroleum ether gave $178 \mathrm{mg}(48 \%)$ of the desired hemiester (PA-hGlu): Mp $128-130^{\circ} \mathrm{C} .[\alpha]_{\mathrm{D}}+100\left(\right.$ c 0.27, $\left.\mathrm{CHCl}_{3}\right) \cdot{ }^{1} \mathrm{H}$ NMR: $\delta 0.60\left({ }^{3} \mathrm{H}, \mathrm{s}, \mathrm{H}-18\right), 0.94\left({ }^{3} \mathrm{H}, \mathrm{s}, \mathrm{H}-19\right), 1.96(2 \mathrm{H}, p, J=14.6$, $\left.\mathrm{H}-3^{\prime}\right), 2.12\left({ }^{3} \mathrm{H}, \mathrm{s}, \mathrm{H}-21\right), 2.38\left({ }^{2} \mathrm{H}, t, J=7.3, \mathrm{H}-2^{\prime}\right), 2.44\left({ }^{2} \mathrm{H}, t, J=7.3\right.$, $\left.\mathrm{H}-4^{\prime}\right), 2.54\left({ }^{1} \mathrm{H}, t, J, 8.8, \mathrm{H}-17\right), 4.75\left({ }^{1} \mathrm{H}, \mathrm{m}, \mathrm{H}-3\right) .{ }^{13} \mathrm{C}$ NMR: $\delta 209.8$ (C-20), 178.4 (COOH), 172.5 (COO), 74.6 (C-3), 64.1 (C-17), 56.9, 44.5, 42.0, 40.6, 39.4, 36.0, 35.2, 34.8, 33.8, 33.1, 32.4, 31.7, 27.1, 26.8, 26.5, 24.6, 23.4, 23.1, 21.0, 20.1, 13.6. IR $\left(\mathrm{CHCl}_{3}\right): 3516(\mathrm{OH}) ; 1711(\mathrm{C}=\mathrm{O})$, $593\left(\mathrm{CH}_{3} \mathrm{CO}\right)$. MS: ESI m/z $455.3(100 \%, \mathrm{M}+\mathrm{Na}), 477.3(35 \%, \mathrm{M}+\mathrm{Na}$ $+\mathrm{H})$. For $\mathrm{C}_{26} \mathrm{H}_{40} \mathrm{O}_{5}(432.3)$ calculated: $72.19 \% \mathrm{C}, 9.32 \% \mathrm{H}$; found: $72.14 \% \mathrm{C}, 9.45 \% \mathrm{H}$.

PA-hAdi. N, $N^{\prime}$-Dicyclohexylcarbodiimide $(410 \mathrm{mg}, 2 \mathrm{mmol})$ in dry benzene $(10 \mathrm{ml})$ was added into a solution of adipic acid $(300 \mathrm{mg}, 2$ $\mathrm{mmol})$ in dry THF $(10 \mathrm{ml})$ under inert atmosphere and the mixture was stirred for $1 \mathrm{~h}$. Then, a solution of PA-OH $(320 \mathrm{mg}, 1 \mathrm{mmol})$ and 4-(dimethylamino)pyridine $(10 \mathrm{mg}, 0.08 \mathrm{mmol})$ in dry benzene $(10 \mathrm{ml})$ was added dropwise over $15 \mathrm{~min}$. This reaction mixture was stirred at room temperature for $16 \mathrm{~h}$ and then the solvents were evaporated. The residue was purified on a column of silica gel (petroleum ether/ether, 9:1) to afford noncrystalizing hemiester $(350 \mathrm{mg}, 78 \%):[\alpha]_{\mathrm{D}}+89$ (c 0.49 , $\left.\mathrm{CHCl}_{3}\right) .{ }^{1} \mathrm{H}-\mathrm{NMR}: \delta 0.60\left(s,{ }^{3} \mathrm{H}(\mathrm{H}-18) ; 0.92\left(s,{ }^{3} \mathrm{H}, \mathrm{H}-19\right) ; 2.11\left(s,{ }^{3} \mathrm{H}\right.\right.$, $\mathrm{H}-21) ; 2.30\left(\mathrm{~m},{ }^{2} \mathrm{H}, \mathrm{W} \sim 20, \mathrm{H}\right.$-adipate); $2.37\left(\mathrm{~m},{ }^{2} \mathrm{H}, \mathrm{W} \sim 20\right.$, H-adipate); $2.53\left(t,{ }^{1} \mathrm{H}, J=9, \mathrm{H}-17\right) ; 4.73(\mathrm{~m}, 1 \mathrm{H}, \mathrm{W}=35, \mathrm{H}-3)$. IR $\left(\mathrm{CHCl}_{3}\right)$ : 1727, $1706(\mathrm{C}=\mathrm{O}) ; 1358\left(\mathrm{CH}_{3} \mathrm{C}=\mathrm{O}\right) ; 1233,1193,1183(\mathrm{C}-\mathrm{O})$. For $\mathrm{C}_{27} \mathrm{H}_{42} \mathrm{O}_{5}$ (446.6) calculated: $72.61 \% \mathrm{C} ; 9.48 \% \mathrm{H}$; found: $72.13 \% \mathrm{C}$; $9.53 \% \mathrm{H}$.

PA-hPim. The same procedure as for PA-hAdi was used. Instead of adipic acid, pimelic acid (heptanedioic acid) was used to produce PAhPim. Oily, $[\alpha]_{\mathrm{D}}+72.3$ (c $\left.0.33, \mathrm{CHCl}_{3}\right) .{ }^{1} \mathrm{H}-\mathrm{NMR}: \delta 0.60\left(s,{ }^{3} \mathrm{H}, \mathrm{H}-18\right)$; $0.93\left(s,{ }^{3} \mathrm{H}, \mathrm{H}-19\right) ; 2.11\left(s,{ }^{3} \mathrm{H}, \mathrm{H}-21\right) ; 2.30$ (m, 2H, W 20, H-pimelate); $2.37(\mathrm{~m}, 2 \mathrm{H}, \mathrm{W} \sim 20$, H-pimelate $) ; 2.53(t, 1 \mathrm{H}, J=8.8) ; 4.74(\mathrm{~m}, 1 \mathrm{H}, \mathrm{W}=$ 35, H-3). ${ }^{13} \mathrm{C}$ NMR (MeOD): $\delta 209.6$ (C-20), 178.6 (COO), 173.2 (COO-), 74.1, 63.9, 56.7, 44.8, 44.3, 41.9, 40.4, 39.2, 35.8, 35.1, 34.6, 34.6, $32.3,31.5,28.7,26.9,26.7,26.3,24.74,24.70,24.4,23.3,22.9,20.9,13.4$ (C-18). IR $\left(\mathrm{CHCl}_{3}\right): 3516$ (COOH, monomer), $1725(\mathrm{C}=\mathrm{O}$, ester $), 1705$ $\left(\mathrm{C}=\mathrm{O}, \mathrm{COCH}_{3}\right), 1261$ (C-O, ester). MS: (ESI): 460 (4\%, M). HR-MS (+ESI) calculated for $\mathrm{C}_{28} \mathrm{H}_{44} \mathrm{O}_{5} \mathrm{Na}[\mathrm{M}+\mathrm{Na}]$ 483.3081, found 483.3080 .

\section{Computational methods}

The relevant physicochemical properties of neuroactive steroids were calculated by quantum mechanics computational methods and by physicochemical properties predictor.

Preparation of structures. The geometries of steroids were obtained by the modeling of the ligand taken from the $\mathrm{x}$-ray structure (3CAV PDB code; Faucher et al., 2008) using PyMOL program (version 1.5.0.4; Schrödinger) and were optimized by the RI-DFT/B-LYP/SVP method with the Turbomole program (Ahlrichs et al., 1989). The empirical dispersion correction (D; Jurecka et al., 2007) and COSMO continuum solvation model (Klamt and Schuurmann, 1993) were used on the gradient optimization. The most stable local minima of the steroids were generated by the quenched molecular dynamics simulation with Amber 14 (Salomon-Ferrer et al., 2013) in explicit water solvent (the simulation was run for $30 \mathrm{~ns}$; the constant temperature was $303 \mathrm{~K}$ ). The parameters were obtained from the GAFF force field. The charges were calculated using the RESP procedure at the HF/6-31G* level (Bayly et al., 1993). The resulting geometries were minimized by the RI-DFT-D/B-LYP/
SVP//COSMO method and their single-point energies were calculated at the RI-DFT-D3/B-LYP/TZVPP level (Grimme et al., 2010).

Docking. Docking with AutoDock was used to sample the conformational variability of steroid molecules in the confined space within the NMDAR. AutoDock 4.2.3 calculations were prepared and analyzed in AutoDockTools (ADT) 1.5.6rc3 (Sanner, 1999). Protein and ligand charges were assigned by ADT using Gasteiger charges. To assess the relative rate of the steroid inhibition onset (the steroid distribution in the channel vestibule), genetic algorithm runs of 50 steps were used within an $80 \times 80 \times 60$ grid $(1 \AA$ spacing $)$ surrounding the extracellular mouth of the model of NMDAR in its activated state (Vyklicky et al., 2015). Combined results of 30 runs (resulting in 675-1400 poses after clustering) were analyzed for each steroid molecule. The electrostatic potential of NMDAR was calculated using the APBS program (Baker et al., 2001) and visualized with the UCSF Chimera package (Pettersen et al., 2004).

Predictions of thermodynamic properties. The solvation free energy $\left(\delta G_{\text {solv }}\right)$ of steroids was calculated in the SMD continuum solvation model (the transfer from vacuum to water and from $n$-octanol to water) at the HF/6-31G* level with Gaussian software. The partition-coefficients $(\log \mathrm{P})$ of water/n-octanol phase were calculated at the M06-2X/6-31G level in SMD with Gaussian as the difference between the total energies in water and in n-octanol. The distribution coefficients $(\log D)$ of water/noctanol phase were predicted by the MarvinSketch program (Marvin 15.1.19, 2015; ChemAxon).

\section{Behavioral methods}

Animals. Experiments were performed on adult albino male Wistar rats (250-350 g) bred by the Institute of Physiology at the Czech Academy of Sciences (CAS). Rats were housed in a controlled environment (temperature $22 \pm 1^{\circ} \mathrm{C}$, humidity $50-60 \%$, lights on $06: 00-18: 00 \mathrm{~h}$ ) with free access to food and water. Experiments were conducted in accordance with the guidelines of the European Union directive 2010/63/EU and approved by the Animal Care and Use Committee of the Institute of Physiology CAS and by The Central Committee of the CAS. The Institute of Physiology possesses the National Institutes of Health Statement of Compliance with Standards for Humane Care and Use of Laboratory Animals.

Open-field test. Spontaneous locomotor activity was recorded in a soundproof MultiConditioning System arena $(45 \mathrm{~cm} \times 45 \mathrm{~cm}$; TSE Systems), and expressed as the total distance traveled during $30 \mathrm{~min}$. PA-hPim at a dose of 1 or $10 \mathrm{mg} / \mathrm{kg}$ was dissolved in $1 \mathrm{ml}$ of $88 \mathrm{~mm}$ hydroxypropyl- $\beta$-cyclodextrine ( $\beta$-CDX), $\mathrm{pH}$ 7.4. MK-801 was dissolved in PBS and given at a dose of $0.1,0.2$, or $0.3 \mathrm{mg} / \mathrm{kg}$. The drugs were applied intraperitoneally $40 \mathrm{~min}$ before behavioral observations; control animals were injected with a corresponding volume of $\beta$-CDX or saline, respectively.

Passive avoidance. The passive avoidance apparatus $(45 \mathrm{~cm} \times 45 \mathrm{~cm})$ consisted of two equally large compartments divided by a sliding door (Multi Conditioning system; TSE Systems). The rats were treated intraperitoneally with saline, $\beta$-CDX, PA-hPim (at 1 or $10 \mathrm{mg} / \mathrm{kg}$ ), or MK-801 (at $0.1,0.2$, or $0.3 \mathrm{mg} / \mathrm{kg}$ ) $30 \mathrm{~min}$ before a habituation session. At the beginning of each session, the rat was placed into the highly illuminated compartment and could avoid this aversive stimulus by crossing to the dark compartment. During the habituation session, the sliding door was lifted and the rat could move freely between the compartments for $5 \mathrm{~min}$. Thirty minutes later, the rat was placed into the arena again for a training session. This time, after crossing to the dark compartment, the sliding door fell down and the rat received a mild electric foot shock $(1.5 \mathrm{~mA}, 5 \mathrm{~s}$ duration) through the stainless steel grid floor. A testing session took place $1 \mathrm{~h}$ after the training session and was conducted in the same way except that the footshock was not activated. The latency to cross into the dark compartment was analyzed.

Spontaneous alternation task in a $Y$-maze. The maze was constructed from Plexiglas with three arms of the same length $(40 \mathrm{~cm} \times 11 \mathrm{~cm})$ interconnected at a $120^{\circ}$ angle. Each rat was placed at the center of the maze at the beginning of the experiment and allowed to explore the maze freely for $10 \mathrm{~min}$. An alternation was defined as sequentially entering all three arms without reentry into a previously visited arm. Percentage alternation was calculated as follows: (alternations/total entries -2 ) $\times$ 
100. Thirty minutes before experimental testing, rats were treated intraperitoneally with saline, $\beta$-CDX, PA-hPim (at the doses of 1 or $10 \mathrm{mg} / \mathrm{kg}$ ), or MK-801 (at the doses of $0.1,0.2$, or $0.3 \mathrm{mg} / \mathrm{kg}$ ). At the dose of $0.3 \mathrm{mg} / \mathrm{kg}, \mathrm{MK}-801$ induced stereotypical behavior precluding data evaluation.

Neuroprotection. Intrahippocampal lesion was induced by a bilateral infusion of $1 \mu \mathrm{l}$ of $25 \mathrm{~mm}$ NMDA (Abcam) dissolved in PBS into the dorsal hippocampus ( $\mathrm{AP}=4 ; \mathrm{L}=2.5 ; \mathrm{DV}=4.8 \mathrm{~mm}$ ). The infusions were performed with a syringe pump (model 540310 plus; TSE Systems) at a constant flow rate of $0.25 \mu \mathrm{l} / \mathrm{min}$. Control animals were either intact, or received an intrahippocampal infusion of $1 \mu \mathrm{l}$ of PBS. Because the two control groups were not statistically different in terms of their performance, they were pooled for subsequent analysis. PA-hPim $(1 \mathrm{mg} / \mathrm{kg}$ in $1 \mathrm{ml}$ of $88 \mathrm{~mm} \beta$-CDX) was injected intraperitoneally 5 min after the NMDA infusion. NMDA-infused animals received either the corresponding volume of intraperitoneal $\beta$-CDX or no treatment; because these two groups were not statistically different, they were pooled for analysis. The animals recovered for 1 week before starting the Morris water maze (MWM) procedures. All drugs, unless otherwise stated, were purchased from Sigma-Aldrich.

MWM experiments were performed as described previously (Mikulecká et al., 2014). The maze was a black-painted circular plastic pool $\left(210 \mathrm{~cm}\right.$ in diameter, $40 \mathrm{~cm}$ high) filled with water $\left(21^{\circ} \mathrm{C}\right)$. Rats were released from one of eight compass points (NW, NE, SE, W, S, N, SW, and $\mathrm{E}$, in this order) at the periphery of the pool and allowed to swim until they found a transparent circular platform $(10 \mathrm{~cm}$ in diameter submerged $1 \mathrm{~cm}$ below the water surface in the center of an arbitrarily chosen quadrant of the pool, SW) or until 60 s elapsed. Training consisted of 8 trials a day for $4 \mathrm{~d}$. The position of the platform was stable throughout the experiment. Training was recorded by a camera placed above the center of the MWM. The videos were analyzed offline by Ethovision XT10 software (Noldus).

\section{Statistical methods}

In electrophysiology experiments, statistical comparisons of groups were performed using Student's $t$ test $(p<0.05$ was used to determine significance). Cumulative distributions of mEPSC amplitudes and interevent intervals were compared using Kolmogorov-Smirnov (K-S) test using a conservative value of $p<0.001$ to determine significance. For behavioral experiments, one-way ANOVA followed by Holms-Sidak post hoc comparisons versus control group or two-way ANOVA followed by StudentNewman-Keuls post hoc tests were used. The results are presented as means \pm SEM, with $n$ indicating the number of cells (electrophysiology experiments) or animals (behavioral experiments).

\section{Results}

\section{Recombinant receptors}

NMDARs are activated phasically by synaptically released glutamate or tonically by extracellular glutamate elevated under pathological conditions. Kinetic simulations indicate that, based on the pharmacological mode of inhibitor action at the NMDAR, a different ratio of phasic over tonic inhibition is expected. Compounds such as PA-S with use-dependent and voltageindependent block and use-independent unblock are likely to preferentially inhibit tonically over phasically activated NMDAR and therefore may have a desirable therapeutic profile (Vyklicky et al., 2014). First, we tested the simulation predictions for PA-S at recombinant GluN1/GluN2B receptors expressed in HEK293 cells and activated by fast agonist application. Figure $2 A$ shows an experiment in which we compared the ability of PA-S $(50 \mu \mathrm{M})$ to inhibit the peak (phasic) response induced by fast $1 \mathrm{~mm}$ glutamate application (solution exchange rate $\sim 10 \mathrm{~ms}$ ) versus the steady-state response after glutamate application for $5 \mathrm{~s}$. A doseresponse analysis indicates that $\mathrm{PA}-\mathrm{S}$ inhibited the peak responses less than the steady-state responses, with a 2 -fold difference in potency (Fig. $2 \mathrm{~B}, C$; peak $\mathrm{IC}_{50}=46 \pm 3 \mu \mathrm{M} ; n=4$; steady-state $\left.\mathrm{IC}_{50}=23 \pm 2 \mu \mathrm{M} ; n=4 ; p<0.001\right)$. We have also tested recombinant GluN1/GluN2A receptors and found an even stronger ( $\sim 6$-fold) selectivity of PA-S for steady-state over peak inhibition (Fig. 2C; peak $\mathrm{IC}_{50}=296 \pm 34 \mu \mathrm{M}$; steady-state $\mathrm{IC}_{50}=$ $53 \pm 7 \mu \mathrm{M} ; n=6 ; p<0.001)$. In an effort to identify novel steroid NMDAR inhibitors with desirable pharmacological properties, we have synthesized a series of 20 -oxo-5 $\beta$-pregnanes substituted in the position $\alpha$ of carbon C3 by carboxyl acids of increasing length (Fig. 1). We then tested these compounds for their ability to inhibit the peak versus the steady-state NMDAR response. Figure $2 D$ illustrates an experiment in which PA-hPim $(30 \mu \mathrm{M})$ was tested for its potency to inhibit peak and steady-state responses of GluN1/GluN2B receptors. Although the steady-state response to glutamate $(1 \mathrm{~mm})$ was inhibited by $66 \pm 4 \%$, the peak response was virtually unaffected $(+0.02 \pm 1.76 \% ; n=8)$ in the continuous presence of PA-hPim. The inhibitory effect was fully reversible within seconds of the steroid wash-out and the degree of the steroid-induced peak inhibition was the same for the first and the subsequent responses made in the presence of the steroid. Remarkably, the $\mathrm{IC}_{50}$ values for the steady-state response inhibition decreased with the length of the substituent aliphatic chain from PA-hOxa to PA-hPim (Fig. 2E), whereas the values of the $\mathrm{IC}_{50}$ for the peak response inhibition remained high. In fact, in the case of PA-hPim, peak response inhibition was so weak, the peak $\mathrm{IC}_{50}$ could not be determined accurately (Fig. 2, legend). The strong selectivity of PA-hPim for steady-state over peak responses was also observed for recombinant GluN1/GluN2A receptors (Fig. 2E).

It was of interest to compare the action of steroid inhibitors with that of memantine, which is approved for the treatment of Alzheimer's disease. Even though both memantine and steroids are use-dependent inhibitors, they differ in the voltage dependency of block and in the trapping versus foot-in-the-door mechanism of action (Blanpied et al., 1997; Petrovic et al., 2005; Vyklicky et al., 2015). Figure $3 A$ shows that both memantine $(10 \mu \mathrm{M})$ and PA-S $(300 \mu \mathrm{M})$ inhibited steady-state GluN1/ GluN2B receptor responses and exhibited pharmacodynamic similarities characterized by a slow offset of inhibition. Importantly, their actions differed when glutamate responses were induced in the continuous presence of the inhibitor to simulate the situation in vivo. In contrast to PA-S (Fig. $2 A$ ), the peak responses to glutamate made in the presence of memantine $(10 \mu \mathrm{M})$ were progressively more inhibited with each glutamate application. This eventually eliminated the difference between the $\mathrm{IC}_{50}$ values for the peak versus the steady-state inhibition by memantine (peak $\mathrm{IC}_{50}=3.1 \pm 0.5 \mu \mathrm{M}$; steady-state $\mathrm{IC}_{50}=2.7 \pm 0.4 \mu \mathrm{M} ; p=$ $0.125 ; n=4)$, with the ratio of the $\mathrm{IC}_{50}$ values being $1.14 \pm 0.04$ (Fig. $3 B$ ), confirming the advantage of steroid NMDAR inhibitors over memantine.

\section{Structure-function relationship of the steroid inhibition of NMDAR}

The complex process of steroid access to the NMDAR can be divided into three steps: (1) the micelles that occur in the extracellular liquid fuse with the membrane, (2) single molecules leave the membrane, and (3) molecules enter into the channel vestibule (Vyklicky et al., 2015). The physicochemical properties relevant to single molecules in water and in the membrane environment are listed in Table 1 . As expected, we found a correlation between binding free energies $\delta G_{\exp }$ calculated from the experimentally determined steady-state $\mathrm{IC}_{50}$ values (Fig. $2 E$ ) and the length of the aliphatic chain. We also found a correlation between $\delta G_{\text {exp }}$ and solvation energies $\delta G_{\text {solv }}$ in the case of the transfer of the steroid molecule from vacuum to water and between $\delta G_{\exp }$ 
A

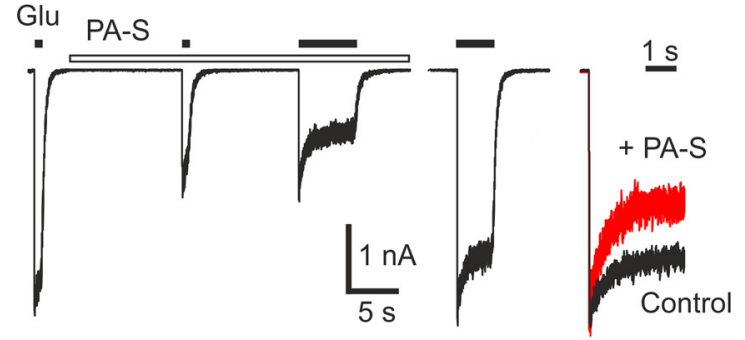

B

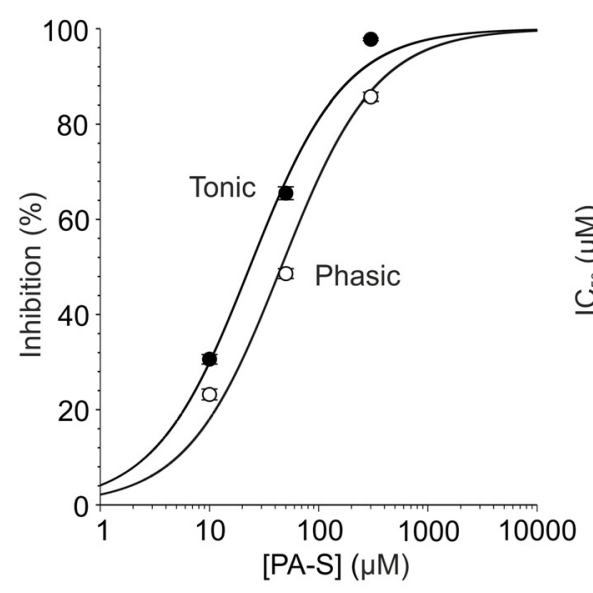

C

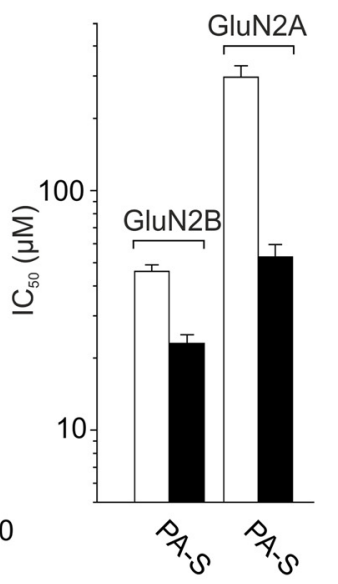

D

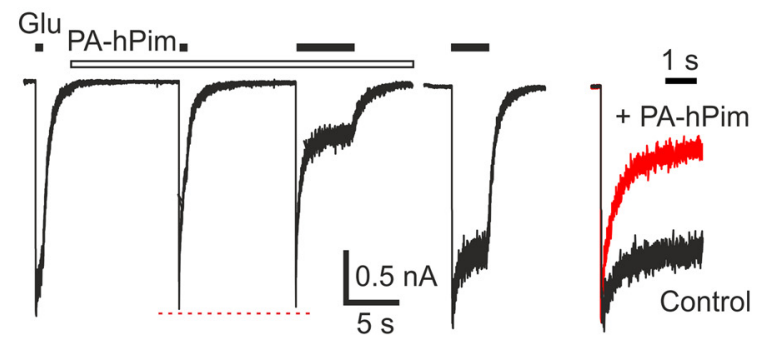

E

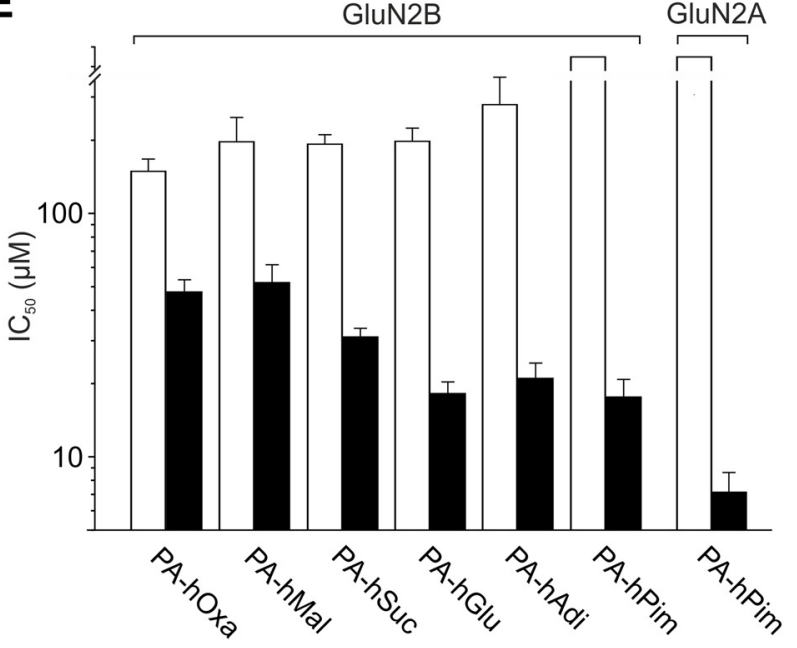

Figure 2. PA-S and its ester analogs are more potent at inhibiting steady-state than peak responses mediated by GluN1/GluN2B or GluN1/GluN2A receptors. $A$, Responses evoked in a HEK293 cell expressing GluN1/GluN2B receptors by fast application of glutamate $(1 \mathrm{~mm})$ for 0.5 and $5 \mathrm{~s}$ in the absence and in the continuous presence of PA-S ( $50 \mu \mathrm{M})$. The duration of glutamate and steroid applications is indicated by filled and open bars, respectively. Right, Control response to glutamate (black) and a response made in the presence of PA-S (red) are shown overlaid and normalized with respect to their peak amplitude. $\boldsymbol{B}$, Dose-response curves for PA-S $(10,50$, or $300 \mu \mathrm{m})$ inhibition of peak NMDAR responses (open symbols) and steady-state NMDAR responses (filled symbols). Data were fitted to Equation 1 and the smooth curves were calculated from the mean $\mathrm{IC}_{50}$ values. $C$, Mean \pm SEM of the $\mathrm{IC}_{50}$ values determined using Equation 2 for PA-S inhibition of the peak responses (open bars) and the steady-state responses (filled bars) of GluN1/GluN2A and GluN1/GluN2B receptors. $\boldsymbol{D}$, Responses induced by glutamate ( $1 \mathrm{~mm}$ ) in the absence and in the continuous presence of PA-hPim $(30 \mu \mathrm{m})$. The duration of glutamate and steroid applications is indicated by filled and open bars, respectively. Right, Control response (black) and a response recorded in the presence of PA-hPim (red) are shown normalized with respect to their peak and overlaid. $E$, Mean $\pm S E M$ of the $\mathrm{IC}_{50}$ values determined using Equation 2 for each hemiester-PA analog from the relative steroid inhibition of the peak responses (open bars) and the steady-state responses (filled bars). The $\mathrm{IC}_{50}$ values for peak inhibition by PA-hPim were calculated from cells in which the steroid induced inhibition (5/8 for GluN1/GluN2B receptors and 5/6 for GluN1/GluN2A receptors).

and $\log \mathrm{D} . \delta G_{\text {solv }}$ is probably influenced by a change of the conformation during the transfer of the steroids from n-octanol to water, which is not possible to describe accurately because of a large numbers of conformers (local minima). Together, these results indicate the importance of solvation energy and lipophilicity (Kudova et al., 2015) for steady-state inhibition.

Two major reasons contribute to the weaker inhibitory effect of steroids at phasically than at tonically activated NMDARs: the first is the use-dependent mechanism of steroid action (binding can start only after receptor activation), shared by all steroids in this study; the second is the slow onset of steroid-induced inhibition, which varies for different steroids (tens to hundreds of miliseconds). We wanted to explore in more detail how steroid structure may influence the rate of the onset of inhibition. The behavior of the steroids inside the NMDAR was modeled by their docking into the NMDAR channel (see Materials and Methods for details). We have used the model of the agonist-induced conformation of the channel vestibule based on our previous analysis of the role of Thr in the SYTAN motif combining experimental and modeling approaches (Vyklicky et al., 2015). The full model of the NMDAR was prepared by homology modeling based on the available crystal structures of AMPA and NMDARs (Sobolevsky et al., 2009; Karakas and Furukawa, 2014; Lee et al., 2014) using the MODELLER 9v6 software suite (Sali and Blundell,
1993). The opening of the channel was modeled by elongating the distance between the pairs of the corresponding C $\alpha$ atoms of the topmost residues within the pore-forming helices of the GluN1 and GluN2B M3 domains. For the docking study, we selected PA-hOxa and PA-hPim, representing the steroids with the smallest and the largest difference in the peak versus the steady-state $\mathrm{IC}_{50}$, respectively (Fig. $2 E$ ). Our modeling results suggest that the cumulative distribution near the Thr ring, the narrowest portion of the channel vestibule and likely the site of inhibitory steroid action (Vyklicky et al., 2015), is higher for PA-hOxa than for PA-hPim (Fig. 4B). Modeling suggests several factors affecting the cumulative distribution (which, as calculated, is indicative of the rate of the steroid inhibition onset). Both hemiester-PA derivatives interact with the whole nonpolar (Fig. $4 A, B$ ) inner surface of the NMDAR channel, mostly through van der Waals interactions. These interactions are influenced by partial desolvation in the place of the interaction, the character of the charged and polar parts of the steroid in the nonpolar surroundings (Barratt et al., 2006), and changes of the steroid conformation. Overall, these interactions result in slowing the rate of steroid access to the site of inhibitory action, particularly for the steroids with longer aliphatic chains, reducing their peak NMDAR current inhibition. To better understand the behavior of steroids inside of the NMDAR channel vestibule, we have investigated the flexibil- 
A
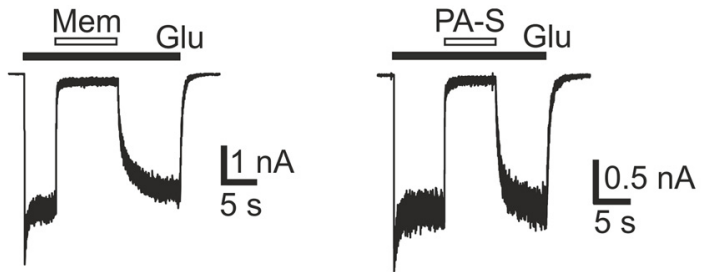

B

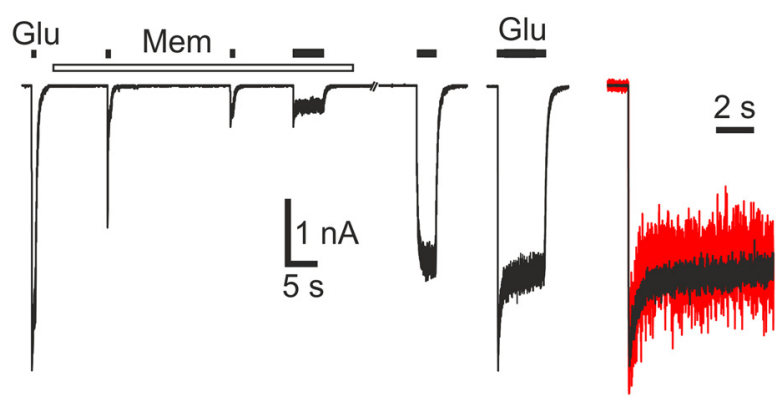

Figure 3. Memantine is only weakly selective for inhibiting tonically over phasically activated GluN1/GluN2B receptors. $A$, Responses evoked by long glutamate (1 mM) applications in HEK293 cells expressing GluN1/GluN2B receptors. Memantine (10 $\mu \mathrm{M})$ or PA-S (300 $\mu \mathrm{M})$ were coapplied with glutamate as indicated. $\boldsymbol{B}$, Responses evoked by fast applications of glutamate $(1 \mathrm{~mm})$ for 0.5 and $5 \mathrm{~s}$ in the absence and in the continuous presence of memantine $(10 \mu \mathrm{M})$. Right, Control response to glutamate (black) and a response made in the presence of memantine (red) are shown overlaid and normalized with respect to their peak amplitude.

ity and conformer stability of steroids in the NMDAR channel and in the water phase. We present changes of the conformation of the single molecule of PA-hPim and of PA-hOxa obtained using a quenched MD simulation in the explicit water phase (Fig. $4 C)$. The deformation energy is expressed as the difference of the single point energies between the global minimum (extended form of the steroid; Fig. $4 C$ ) and the local minimum (compact conformer inside the NMDAR). For PA-hPim, the deformation energy is $5.87 \mathrm{kcal} / \mathrm{mol}$ for permittivity $\varepsilon=78.4$, but only 3.91 $\mathrm{kcal} / \mathrm{mol}$ for $\varepsilon=4$, and $5.16 \mathrm{kcal} / \mathrm{mol}$ for $\varepsilon=10$ (the $\varepsilon$ values characterize the permittivity of implicit solvents; the first describes the water phase and the other two are commonly used for protein interior). The cumulative distribution of the compact local minimum is $\sim 5 \%$ in the explicit water phase and $\sim 30 \%$ inside the NMDAR channel for PA-hPim (Fig. 4C). These data indicate that PA-hPim is flexible and tends to adopt a more compact conformation inside the NMDAR through an intramolecular interaction of the aliphatic chain to the steroid skeleton. This intramolecular interaction has an adverse energy effect, but facilitates steroid passage to the gating Thr residues (Beck et al., 1999; Sobolevsky et al., 2002; Vyklicky et al., 2015). In contrast, the conformation of PA-hOxa inside the channel vestibule remains mostly extended (Fig. 4C). Together, our results suggest that interactions of steroids with the longer aliphatic chains with the nonpolar receptor interior, together with their flexibility, influence their rate of access to the site of their inhibitory action.

\section{Native receptors}

Next, we tested the effects of steroids on native NMDARs activated during synaptic transmission. We recorded autaptic EPSCs from solitary hippocampal neurons grown on micro-islands. To facilitate comparisons with recombinant receptor experiments, we conducted synaptic experiments at room temperature. In the presence of $2 \mathrm{mM} \mathrm{Ca}^{2+}$ and no added $\mathrm{Mg}^{2+}$, we detected both the AMPAR and the NMDAR components of EPSCs. PA-S (100 $\mu \mathrm{M})$ applied for $1.5 \mathrm{~min}$ increased the amplitude of the AMPAR com- ponent of the EPSC by $51 \pm 5 \%(p=0.001 ; n=8)$ while decreasing the amplitude of the NMDAR component of the EPSC by $26 \pm 5 \%(p=0.002 ; n=8)$ compared with baseline (Fig. $5 A)$. The time course of deactivation of the NMDAR component of the EPSC was typically best fit by a double exponential function, from which we calculated $\tau_{\mathrm{w}}$. Consistent with its use-dependent NMDAR block, PA-S $(100 \mu \mathrm{M})$ significantly decreased $\tau_{\mathrm{w}}$ from $177 \pm 16 \mathrm{~ms}$ to $156 \pm 13 \mathrm{~ms}(p=0.014 ; n=8)$. This was largely due to a decrease in $\tau_{\mathrm{s}}(p=0.040)$; there was no significant effect on $\tau_{\mathrm{f}}(p=0.071)$ or the relative proportion of $\tau_{\mathrm{f}}(p=0.413)$.

We wanted to determine whether the mechanism underlying the potentiation of the AMPA EPSC amplitude was presynaptic or postsynaptic. To examine steroid effects on release probability, we examined the paired-pulse ratio of pharmacologically isolated, AMPAR-mediated evoked EPSCs. The amplitude of pure AMPAR EPSCs increased during $100 \mu \mathrm{M}$ PA-S application to the same extent as was observed for the AMPAR component of the dual EPSCs (Fig. 5B, $66 \pm 11 \%$; $p=0.219$ for the comparison between the potentiation of AMPAR component of the dual EPSC vs pure AMPAR EPSC). The paired-pulse ratio of AMPAR EPSCs was $0.81 \pm 0.06$ before steroid application and declined to $0.48 \pm 0.05(p=0.001 ; n=5)$ after $1.5 \mathrm{~min}$ PA-S $(100 \mu \mathrm{M})$ application, suggesting that PA-S potentiates AMPAR EPSCs through a presynaptic mechanism. To confirm this, we recorded AMPA mEPSCs in the presence of TTX (Fig. $5 C, D$ ). In agreement with the decrease in the paired-pulse ratio (indicating a presynaptic effect), the frequency of AMPA mEPSCs was significantly increased by $100 \mu \mathrm{M}$ PA-S (by $194 \pm 41 \%$ of baseline; $p=0.006$; $n=6$ ). K-S tests confirmed that PA-S significantly shortened interevent intervals in $5 / 6$ cells (Fig. $5 D$ ). In contrast, PA-S had no effect on AMPA mEPSC amplitude $(-0.8 \pm 5.3 \% ; p=0.662 ; n=$ 6). Cumulative distribution of AMPA mEPSC amplitudes was significantly altered in only $1 / 6$ cells (Fig. $5 D$ ). The lack of a postsynaptic effect of PA-S on AMPARs was confirmed by examining responses induced by AMPA $(5 \mu \mathrm{M})$ application to cultured hippocampal neurons. Responses to AMPA recorded in the presence of cyclothiazide $(10 \mu \mathrm{M})$ were inhibited by PA-S $(100 \mu \mathrm{M})$ by only $7.2 \pm 1.0 \%$ of control $(n=6$; Fig. $5 E)$.

Next, we compared the inhibition of tonically versus synaptically activated native NMDARs by PA-S. PA-S (100 $\mu \mathrm{M})$ strongly inhibited tonic currents evoked by $300 \mu \mathrm{M}$ NMDA (Fig. $5 F$ ), on average by $81 \pm 1 \%(n=14$; red symbol in Fig. $5 G)$. These data were used to determine the PA-S $\mathrm{IC}_{50}$ for tonic inhibition of native NMDARs ( $30 \pm 1 \mu \mathrm{M} ; n=14$ ). Given our result that PA-S potentiates glutamate release without affecting AMPARs postsynaptically, the ratio of the NMDAR/AMPAR component of the dual EPSC can be used as an indicator of the steroid effect at postsynaptic NMDARs (independent of its presynaptic effect). Figure $5 G$ shows that the normalized amplitude of NMDAR EPSC decreased in the presence of $100 \mu \mathrm{M}$ PA-S by $51 \pm 3 \%$ ( $p<$ $0.001 ; n=8$ ). This was significantly different from the degree of the tonic current inhibition (Fig. $5 F$ and red symbol in Fig. $5 G$; $p<0.001$ ). We used the degree of NMDAR EPSC inhibition by $100 \mu \mathrm{M}$ PA-S (Eq. 2) to calculate the PA-S IC $_{50}$ at postsynaptic NMDARs $(100 \pm 10 \mu \mathrm{M} ; n=8)$. These results demonstrate that PA-S is $\sim 3$-fold more potent at inhibiting tonically over synaptically activated NMDARs. We also examined PA-S inhibition of tonic currents evoked by $10 \mu \mathrm{M}$ NMDA (data not shown) because the degree of inhibition is expected to depend on agonist concentration. PA-S $(100 \mu \mathrm{M})$ inhibited tonic currents evoked by $10 \mu \mathrm{M}$ NMDA by $71 \pm 3 \%(n=9)$, so a more conservative estimate of the PA-S IC ${ }_{50}$ for tonic current inhibition is $50 \pm 7 \mu \mathrm{M}$, still 2-fold lower than the $\mathrm{IC}_{50}$ for PA-S inhibition of NMDAR EPSCs. 
Table 1. Quantitative characteristics of PA analogs

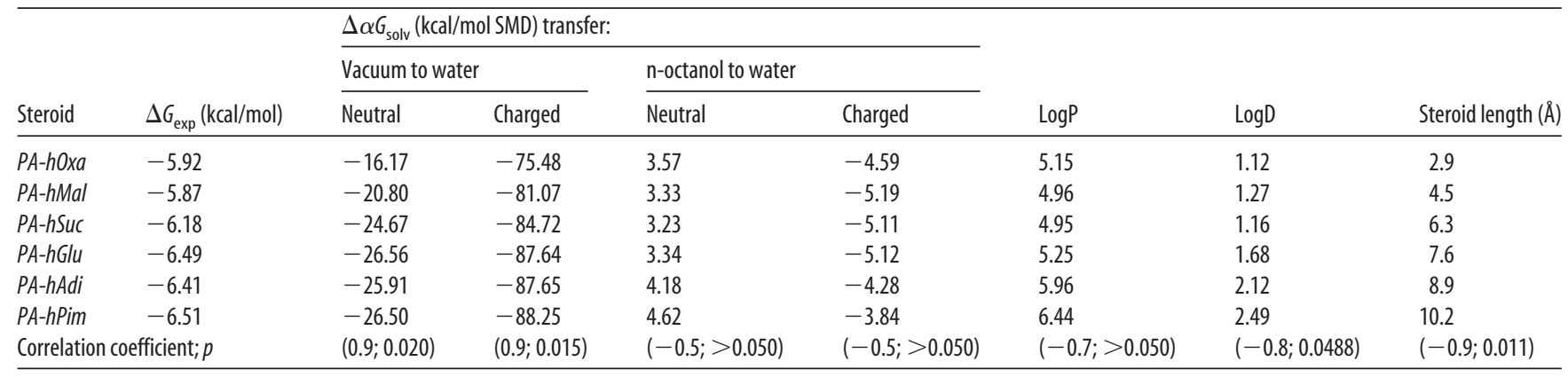

The experimental binding free energies $\left(\Delta G_{\text {exp }}\right)$ expressed from the $\mathrm{I}_{50}$ values via the equation $\delta G_{\text {exp }}=R T \ln \left(\mathrm{IC}_{50}\right)$ were compared with the calculated values of $\Delta G_{\text {solv }}$, LogP, and LogD. The negative values of $\Delta G_{\text {solv }}$ indicate the energy gained and the positive values indicate the energy required during the transfer from the first phase to the second phase. Linear regression was used for the correlation between $\Delta G_{\text {exp }}$ and the calculated data. The Pearson correlation coefficient was used to determine how well the calculated data approximate the experimental data; the values of $r$ and $p$ are given in parentheses. Steroid length indicates the distance spanning the carboxyl moiety and the $\mathrm{C} 3$ carbon.

A

B
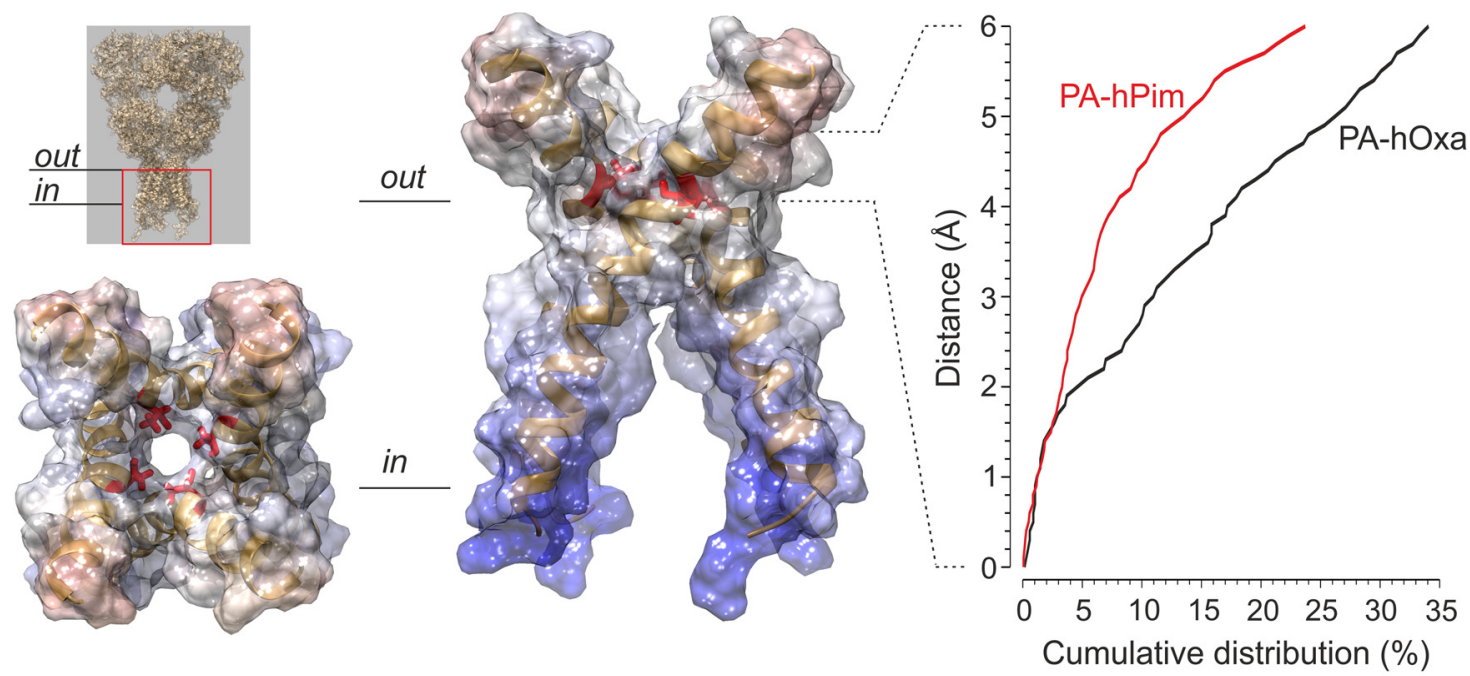

C

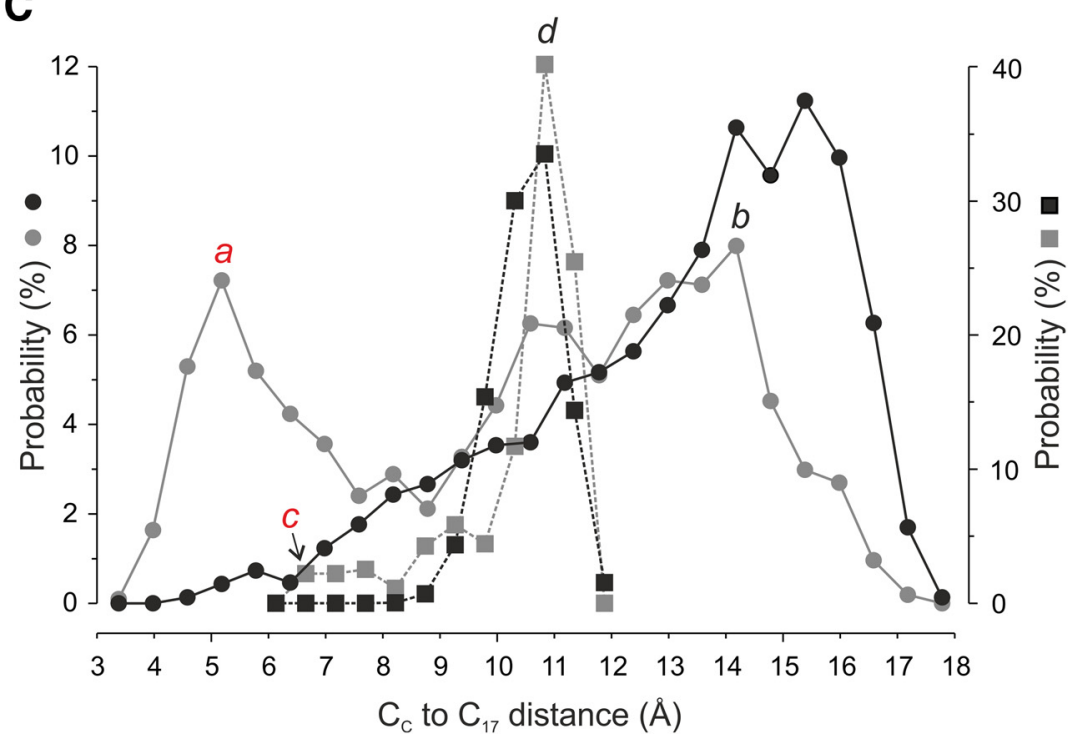

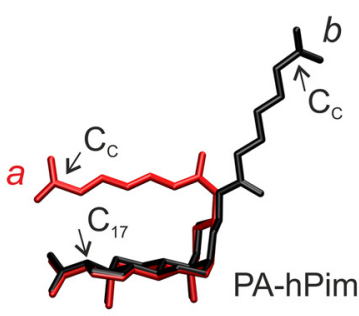

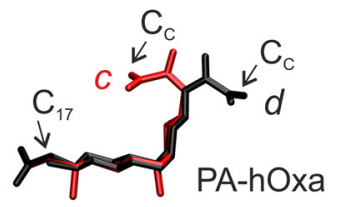

Figure 4. Interaction of steroids with the model of the activated state of the NMDAR. A, M3 helices in the model of the activated state of NMDAR. Gating Thr residues are shown as red sticks. The surface is colored according to the electrostatic potential (blue/white/red as positive/neutral/negative). $\boldsymbol{B}$, Results of a docking analysis showing the probability of finding PA-h0xa and PA-hPim derivatives within the channel vestibule. It was assessed as the vertical distance between the nearest steroid atom to the plane defined by the $C \alpha$ of the threonines (648/647). The position of Thr residues is marked with the bottom dashed line. C, Difference between the distribution of PA-hPim conformers in the water environment (obtained from the MD quench, black curve) compared with the interior of the activated channel (from the docking, gray curve) shown as the distance from the terminal carboxyl group to the C17 carbon of the steroid skeleton. 
A

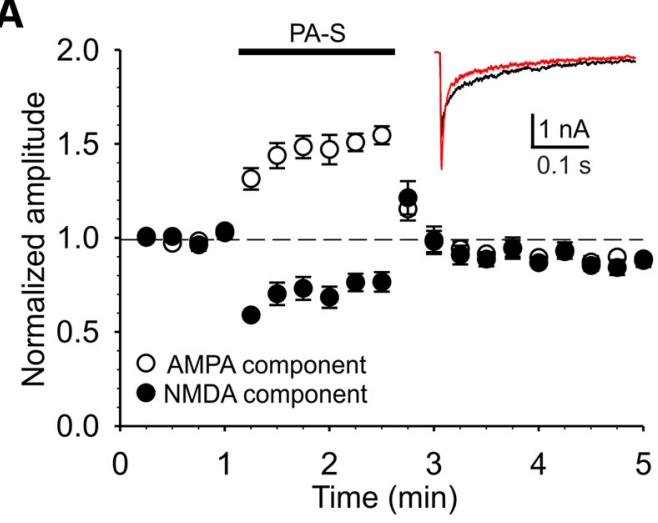

C

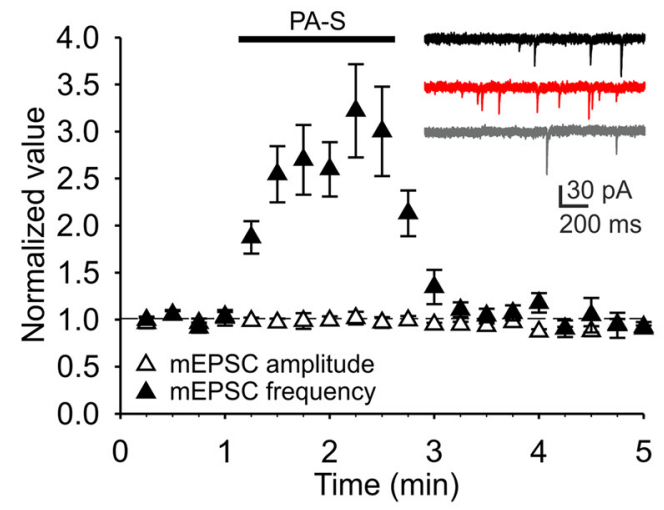

E

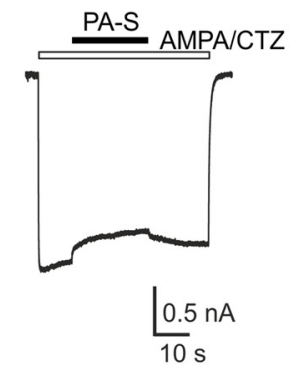

H

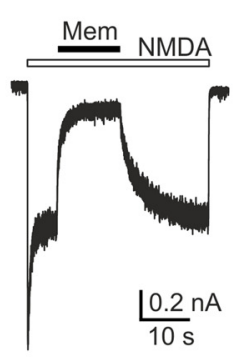

B

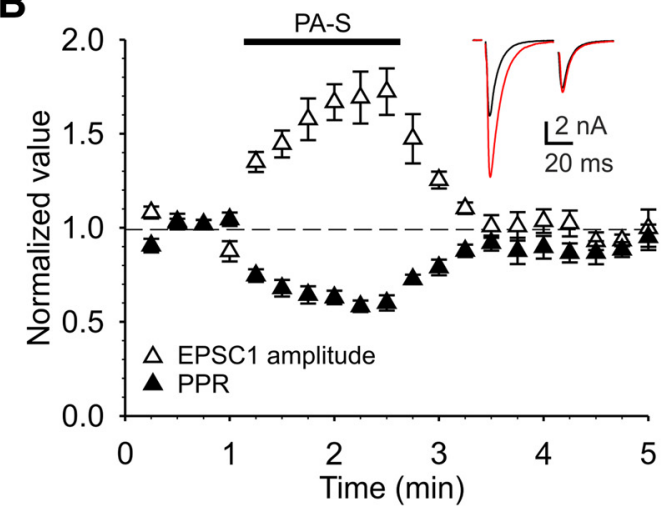

D

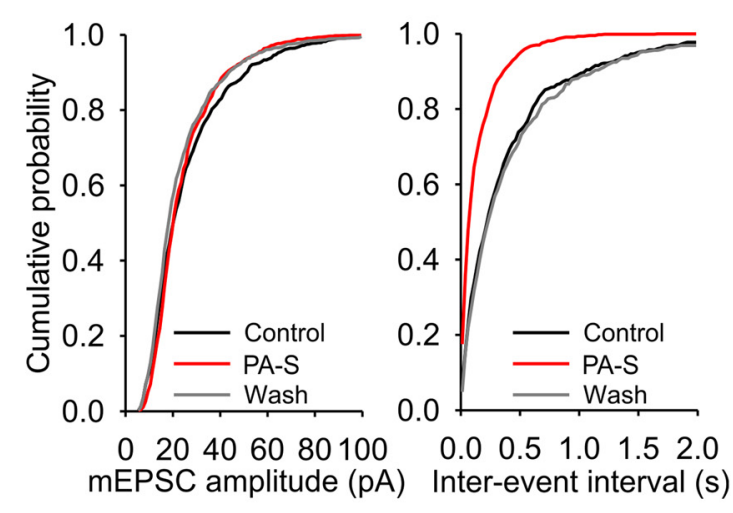

G

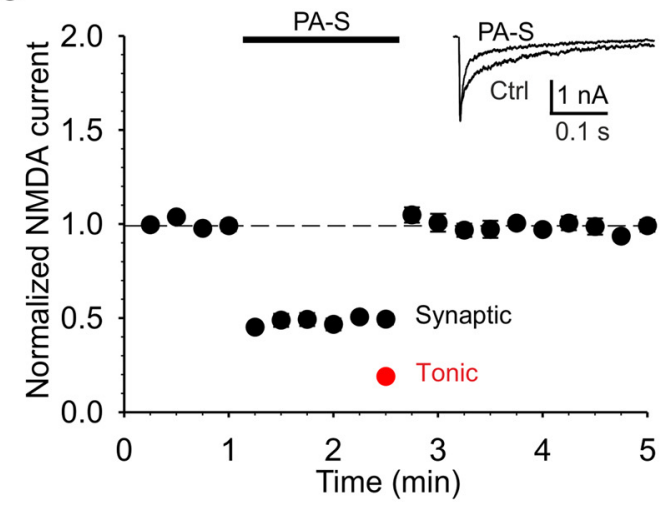

I

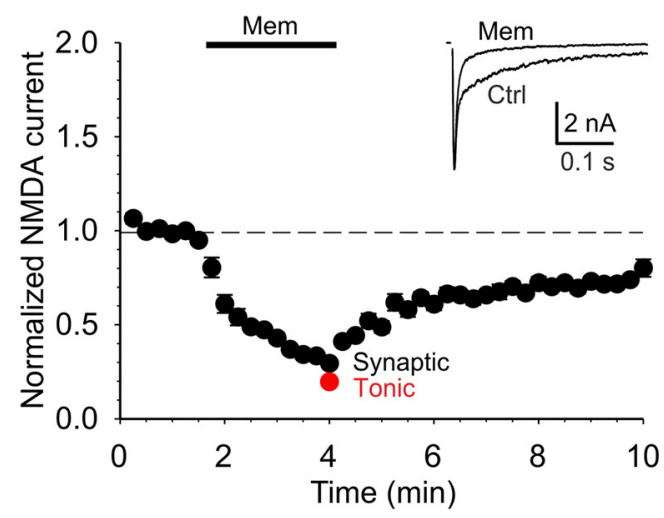

Figure 5. Effects of PA-S on native receptors and synaptic transmission. $A$, Plot of the normalized amplitude of the AMPAR and the NMDAR component of dual EPSCS recorded before, during, and after $100 \mu \mathrm{M}$ PA-S application. Inset, Sample dual EPSC traces recorded in control (black) and in the presence of $100 \mu \mathrm{M}$ PA-S (red). B, Plot of the normalized amplitude and paired-pulse ratio of pharmacologically isolated AMPAR EPSCs recorded before, during, and after PA-S (100 $\mu \mathrm{M})$ application. Inset, Sample AMPAR EPSC traces recorded in control (black) and in the presence of $100 \mu \mathrm{M}$ PA-S (red). C, Plot of the normalized AMPA mEPSC amplitude and frequency recorded before, during, and after PA-S (100 $\mu \mathrm{M})$ application. Inset, Sample traces (Figure legend continues.) 
The degree of PA-S selectivity for tonic over synaptic inhibition is similar to or higher than that reported for memantine (Xia et al., 2010; Emnett et al., 2013) and we wanted to confirm this in our system. Memantine (5 $\mu \mathrm{M})$ inhibited tonic currents evoked in cultured hippocampal neurons by $300 \mu \mathrm{M}$ NMDA by $80 \pm 2 \%$ (Fig. $5 \mathrm{H} ; n=6$ ), so the resulting memantine $\mathrm{IC}_{50}$ for tonic inhibition was $1.6 \pm 0.2 \mu \mathrm{M}$. To examine synaptic effects of memantine, we again recorded dual EPSCs. The AMPAR component of the dual EPSC (data not shown) was unaffected by memantine ( 5 $\mu \mathrm{M})$ applied for $2.5 \min (+2.4 \pm 1.3 \% ; n=6)$ and remained stable throughout the $10 \mathrm{~min}$ recording. In contrast, memantine inhibited the NMDAR component of the dual EPSC by $67 \pm 2 \%$ $(p<0.001 ; n=6)$. This effect had a slow onset and was only partially reversible in the time of the experiment. The degree of the NMDAR EPSC inhibition by memantine (Fig. 5I) was used to calculate the memantine $\mathrm{IC}_{50}$ at postsynaptic NMDARs (2.5 \pm $0.1 \mu \mathrm{M} ; n=6)$. Therefore, under our conditions, memantine is $\sim 1.5$-fold more potent at inhibiting tonic over synaptic NMDAR currents.

We tested the most promising PA-S analog, PA-hPim, at native NMDARs activated phasically during synaptic transmission versus tonically by prolonged agonist application. After PA-hPim $(15 \mu \mathrm{M})$ application for $1.5 \mathrm{~min}$, the amplitude of both components of the dual EPSC increased slightly relative to baseline (by $9.3 \pm 9.0 \%$ for AMPA and by $21 \pm 10 \%$ for NMDA; $n=10$; Fig. $6 A$ ). At the same time, PA-hPim significantly decreased $\tau_{\mathrm{w}}$ of the NMDAR component of the dual EPSC from $213 \pm 5 \mathrm{~ms}$ to $170 \pm$ $13 \mathrm{~ms}(p=0.007 ; n=10)$. This was due to a decrease in $\tau_{\mathrm{s}}(p=$ $0.006)$ and $\tau_{\mathrm{f}}(p=0.002)$, without a change in the relative proportion of $\tau_{\mathrm{f}}(p=0.876)$. To distinguish presynaptic and postsynaptic effects of PA-hPim, we again examined pharmacologically isolated AMPAR EPSCs. The amplitude of AMPAR EPSCs increased during $15 \mu \mathrm{M}$ PA-hPim application (Fig. 6B, by $30 \pm 11 \% ; p=0.201$ for the comparison between the potentiation of AMPAR component of the dual EPSC vs pure AMPAR EPSC). The paired-pulse ratio of AMPAR EPSCs was $0.67 \pm 0.05$ before steroid application and tended to decrease to $0.61 \pm 0.06$ $(p=0.084 ; n=7)$ after 1.5 min of PA-hPim application. In agreement with the tendency to decrease the paired-pulse ratio, PA-hPim increased the frequency of AMPAR mEPSCs by $206 \pm$ $90 \%$ of baseline ( $p=0.031 ; n=6$; Fig. $6 C)$, with a minimal effect on AMPAR mEPSC amplitude $(+5.4 \pm 2.0 \%, p=0.065 ; n=6)$. The analysis of the cumulative distribution of interevent intervals by the K-S test showed a significant shift toward lower values in the presence of PA-hPim in 5/6 cells. In contrast, the cumulative

\footnotetext{
$\leftarrow$

(Figure legend continued.) recorded in control (black), in the presence of $100 \mu \mathrm{M} \mathrm{PA-S}$ (red), and after PA-S washout (gray). D, Mean cumulative probability plots of AMPA mEPSC amplitudes and interevent intervals. $\boldsymbol{E}$, Response of a cultured hippocampal neuron to AMPA (5 $\mu \mathrm{M}$, in the presence of $10 \mu \mathrm{m}$ (TZ), illustrating the small steady-state AMPAR current inhibition by PA-S $(100 \mu \mathrm{M}) . \boldsymbol{F}$, Response of a cultured hippocampal neuron to NMDA (300 $\mu \mathrm{M})$ illustrating the robust steady-state NMDAR current inhibition by PA-S $(100 \mu \mathrm{M})$. G, Plot of the normalized ratio of the NMDAR/AMPAR EPSC amplitude calculated from data shown in $\boldsymbol{A}$ (synaptic NMDAR currents, black symbols). Mean \pm SEM of the normalized steady-state NMDA-evoked current in the presence of $100 \mu \mathrm{m}$ PA-S obtained from experiments illustrated in $\boldsymbol{F}$ (tonic NMDAR currents, red symbol). Inset shows dual EPSC traces in control and in the presence of PA-S (100 $\mu \mathrm{M})$ normalized to the control peak (AMPA) EPSC amplitude. $\boldsymbol{H}$, Response of a cultured hippocampal neuron to NMDA $(300 \mu \mathrm{m})$ illustrating the steady-state current inhibition by memantine ( 5 $\mu \mathrm{M}) . I$, Plot of the normalized ratio of the NMDAR/AMPAR EPSC amplitude (synaptic NMDAR currents, black symbols). Also shown is the mean \pm SEM of the normalized steady-state NMDAevoked current in the presence of $5 \mu \mathrm{m}$ memantine obtained from experiments illustrated in $\boldsymbol{H}$ (tonic NMDAR currents, red symbol). Inset, Dual EPSC traces in control and in the presence of memantine $(5 \mu \mathrm{M})$ normalized to the control peak (AMPA) EPSC amplitude.
}

distribution of mEPSC amplitudes was altered in only $2 / 6$ cells tested (Fig. 6D). Together, these data indicate that PA-hPim, like PA-S, potentiates AMPAR EPSCs largely through a presynaptic mechanism. Accordingly, responses to AMPA $(5 \mu \mathrm{M})$ recorded in the presence of cyclothiazide $(10 \mu \mathrm{M})$ were inhibited by PA-hPim $(15 \mu \mathrm{M})$ by only $3.7 \pm 1.0 \%$ of control ( $n=6$; Fig. $6 E)$.

Next, we compared the inhibition of tonically versus synaptically activated native NMDARs by PA-hPim. PA-hPim (15 $\mu \mathrm{M})$ robustly inhibited tonic $300 \mu \mathrm{M}$ NMDA-evoked currents (Fig. $6 F)$, on average by $70 \pm 2 \%(n=6$; red symbol in Fig. $6 G)$. These data were used to determine the PA-hPim $\mathrm{IC}_{50}$ for tonic inhibition of native NMDARs $(7.4 \pm 0.6 \mu \mathrm{M} ; n=6)$. A more conservative estimate, determined from PA-hPim $(15 \mu \mathrm{M})$ inhibition of tonic currents evoked by $10 \mu \mathrm{M} \mathrm{NMDA}$, was $12 \pm 1 \mu \mathrm{M}(n=6)$. To examine the effect of PA-hPim on synaptically activated NMDARs, we again used the ratio of the NMDAR/AMPAR component of the dual EPSC as an indicator of the steroid effect at postsynaptic NMDARs. Similarly to experiments on recombinant receptors, PA-hPim did not inhibit synaptically activated NMDARs (Fig. 6G). In fact, the normalized amplitude of NMDAR EPSCs increased slightly in the presence of $15 \mu \mathrm{M}$ PAhPim, by $12 \pm 4 \%(p=0.011 ; n=10)$. It was therefore not possible to calculate the $\mathrm{IC}_{50}$ for PA-hPim inhibition of synaptically activated NMDARs, further emphasizing the remarkable selectivity of this novel synthetic steroid for inhibiting tonically activated NMDARs.

\section{Behavioral experiments}

Neuroprotective effects have been described for different classes of NMDAR antagonists, but their systemic application often leads to serious side effects ranging from motor impairment to the induction of schizophrenic-like psychosis (Krystal et al., 1994; Newcomer and Krystal, 2001). Therefore, we examined behavioral effects of systemic PA-hPim administration with the aim of testing its psychomimetic and neuroprotective activity. Psychomimetic symptoms were assessed first by monitoring locomotor activity in the open field (Bubser et al., 1992). Systemic PA-hPim administration $(1 \mathrm{mg} / \mathrm{kg}$ or $10 \mathrm{mg} / \mathrm{kg}$ ) did not induce hyperlocomotion (Fig. 7A). The higher dose tended to decrease the total distance traveled (ANOVA: $p=0.022$ ), but the post hoc comparisons of PA-hPim versus $\beta$-CDX detected no significant differences. In contrast, the administration of MK-801 (0.2 and $0.3 \mathrm{mg} / \mathrm{kg}$ ) caused a robust increase in locomotion (Fig. 7A; ANOVA: $p=0.023)$. Potential cognitive side effects of PA-hPim were assessed by testing spatial cognition in a step-through passive avoidance task and by testing working memory in a spontaneous alternation task in the Y-maze (Parada-Turska and Turski, 1990). The administration of PA-hPim (1 or $10 \mathrm{mg} / \mathrm{kg}$ ) had no effect on performance in the step-through passive avoidance test (Fig. $7 B$; ANOVA: $p=0.057$ ). In contrast, MK-801 completely disrupted learning in the passive avoidance task at all doses tested (Fig. 7B; ANOVA: $p<0.001)$. Similarly, PA-hPim $(1 \mathrm{mg} / \mathrm{kg}$ or 10 $\mathrm{mg} / \mathrm{kg}$ ) had no effect on spontaneous alternation in the Y-maze (Fig. 7C; ANOVA: $p=0.067$ ), whereas MK-801 reduced performance (Fig. $7 C$; ANOVA: $p=0.015$ ). Together, these tests confirm the lack of undesirable psychomimetic and cognitive side effects of PA-hPim, in contrast to the NMDAR channel blocker MK-801, which causes significant hyperlocomotion and cognitive impairment.

We tested PA-hPim neuroprotective potential in a model of NMDA-induced hippocampal lesion. We tested spatial learning in the MWM for three groups of animals (see Materials and Methods): controls, animals with an intrahippocampal infusion 
A

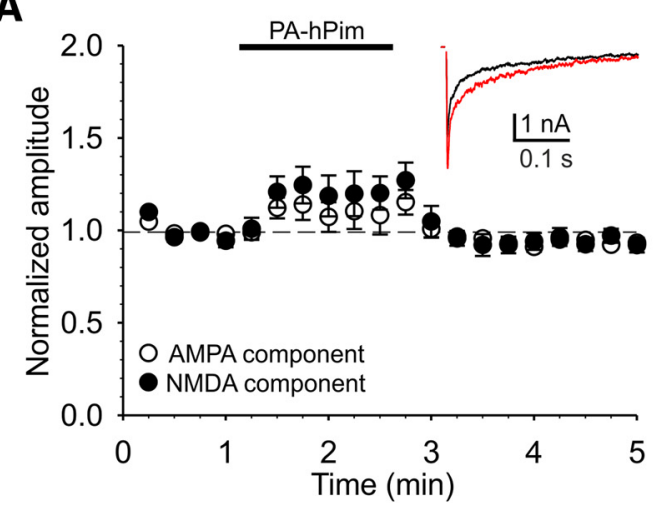

C

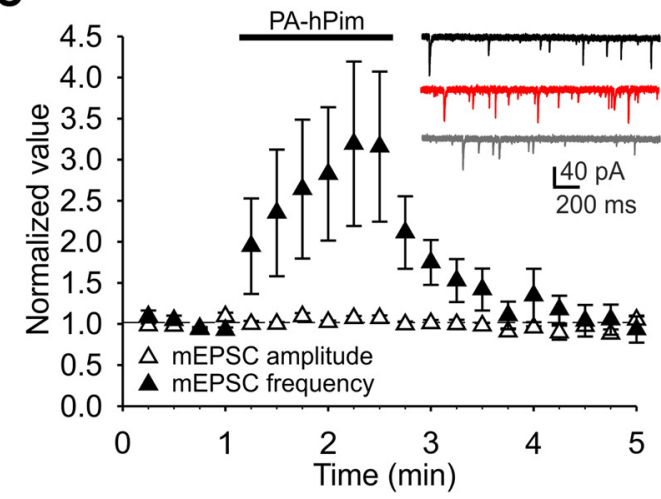

E

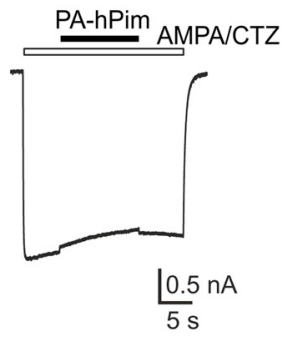

F

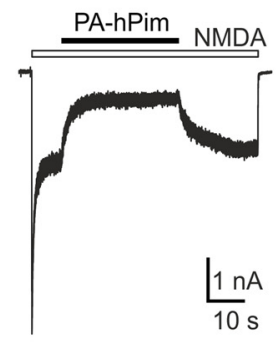

B

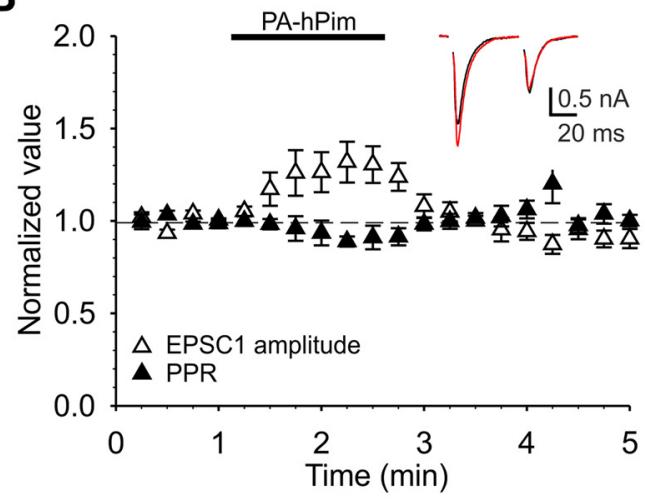

D

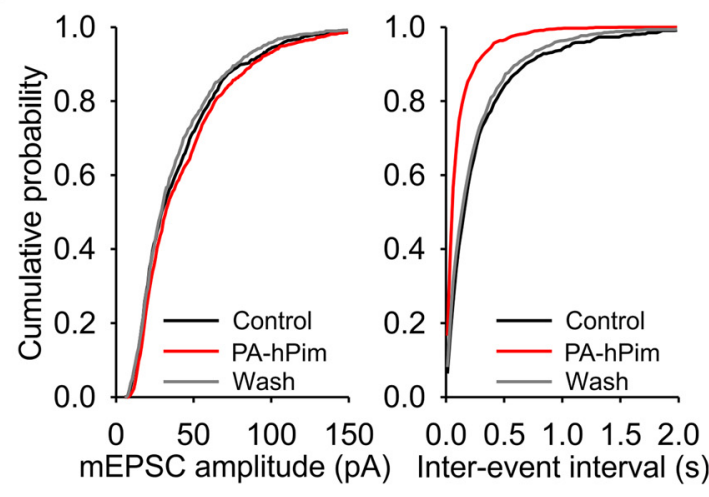

G

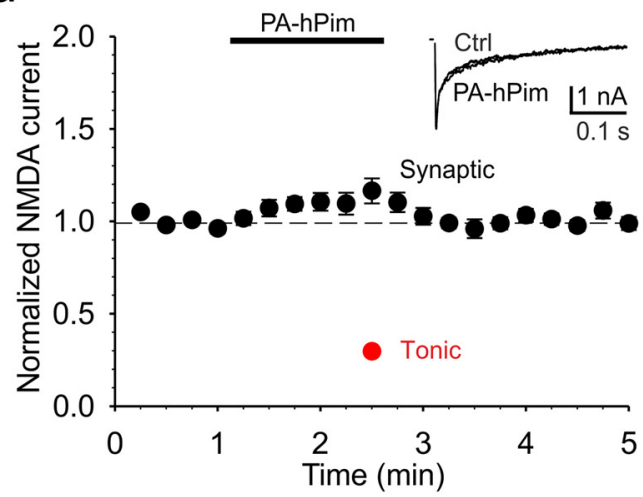

Figure 6. Effects of PA-hPim on native receptors and synaptic transmission. A, Plot of the normalized amplitude of the AMPAR and the NMDAR component of the dual EPSCs recorded before, during, and after $15 \mu \mathrm{m}$ PA-hPim application. Inset, Sample dual EPSC traces recorded in control (black) and in the presence of $15 \mu \mathrm{M}$ PA-hPim (red). B, Plot of the normalized AMPAR EPSC amplitude and paired-pulse ratio recorded before, during, and after PA-hPim (15 $\mu$ M) application. Inset, Sample AMPAR EPSC traces recorded in control (black) and in the presence of $15 \mu \mathrm{M}$ PA-hPim (red). C, Plot of the normalized AMPAR mEPSC amplitude and frequency recorded before, during, and after PA-hPim (15 $\mu \mathrm{m}$ ) application. Inset, Sample traces recorded in control (black), in the presence of $15 \mu \mathrm{M}$ PA-hPim (red), and after PA-hPim washout (gray). D, Mean cumulative probability plots of AMPAR mEPSC amplitudes and interevent intervals. $\boldsymbol{E}$, Response of a cultured hippocampal neuron to AMPA (5 $\mu \mathrm{m}$, in the presence of $10 \mu \mathrm{M}$ CTZ) illustrating the small steady-state AMPAR current inhibition by PA-hPim (15 $\mu \mathrm{M})$. $\boldsymbol{F}$, Response of a cultured hippocampal neuron to NMDA (300 $\mu \mathrm{M}$ ) illustrating the robust steady-state NMDAR current inhibition by PA-hPim $(15 \mu \mathrm{M})$. G, Plot of the normalized ratio of the NMDAR/AMPAR EPSC amplitude calculated from data shown in $\boldsymbol{A}$ (synaptic NMDAR currents, black symbols). Also shown is the mean \pm SEM of the normalized steady-state NMDA-evoked current in the presence of $15 \mu \mathrm{m}$ PA-hPim obtained from experiments illustrated in $\boldsymbol{F}$ (tonic NMDAR currents, red symbol). Inset, Dual EPSC traces in control and in the presence of PA-hPim (15 $\mu \mathrm{m}$ ) normalized to the control peak (AMPA) EPSC amplitude.

of NMDA, and animals with an intrahippocampal infusion of NMDA followed by a systemic administration of $1 \mathrm{mg} / \mathrm{kg}$ PAhPim (Fig. 7D). Our results indicate that all groups successfully learned to navigate to the hidden goal in the MWM, but the NMDA-lesioned group showed slower learning and this was especially apparent on day 2 of the training. Systemic administration of PA-hPim $(1 \mathrm{mg} / \mathrm{kg})$ after the NMDA infusion eliminated this learning deficit (Fig. 7D; two-way RM ANOVA: effect of training day $p<0.001$; effect of group $p=0.113$; interaction $p=$
0.004). Together, our behavioral results show that PA-hPim has neuroprotective properties without psychomimetic side effects.

\section{Discussion}

Our study demonstrates that endogenous neurosteroid PA-S and its analogs are effective antagonists of tonically activated NMDARs with a smaller or no effect on the amplitude of NMDAR EPSCs. Further, we show that steroids have a neuroprotective effect against cognitive deficits induced by NMDA infu- 
sion into the hippocampus, but, in contrast to MK-801, they do not induce psychomimetic symptoms in experimental animals.

\section{Steroid inhibition of tonically and} phasically activated NMDARs

We find that PA-S and its synthetic analogs inhibit tonically activated GluN1/ GluN2A or GluN1/GluN2B receptors with a higher potency than phasically activated receptors. For GluN1/GluN2B receptors, this difference in potency was $\sim 2$-fold for the endogenous steroid PA-S and $\sim 3$-fold for synthetic steroids with a short substituent, such as PA-hOxa. Remarkably, PA-hPim, the synthetic derivative with the longest substituent, exhibited no effect at phasically activated receptors while inhibiting tonically activated receptors. To avoid the effect of slow steroid diffusion to the site of action at the NMDAR (Borovska et al., 2012; Vyklicky et al., 2015), the inhibition of tonically and phasically activated NMDAR was estimated from responses made in the continuous presence of the steroid. Due to the nature of the steroid-receptor interaction, the onset of inhibition is slow (hundreds of milliseconds) compared with the relatively fast onset of the NMDAR responses induced by $1 \mathrm{~mm}$ glutamate (tens of milliseconds). This difference, together with the fact that PA-S binding to the NMDAR can occur only in the presence of the agonist (i.e., it is use dependent; Petrovic et al., 2005; Kussius et al., 2009; Vyklicky et al., 2015), underlie the lower sensitivity of the peak versus the steady-state NMDAR response to inhibitory steroids.

PA derivatives with longer aliphatic chains show slower onset of inhibition compared with PA-S, which is important for their strong selectivity for steady-state over peak NMDAR responses. Our computational study suggests that steroids have a nonspecific affinity to the whole inner surface of the NMDAR channel vestibule. These nonpolar steroid-receptor interactions are accompanied by an induced change of the conformation of the steroids in the channel vestibule. The inhibitor with the longest chain (PA-hPim) forms intramolecular interactions between the steroid skeleton and the aliphatic chain, which enables it to attain a more compact conformation. The character of the inhibition (Fig. 2D) can be explained by the balance between the effect of the conformation change and the increase of the interaction energy due to the growing number of the interacting atoms. This process is slow because of a series of successive associations and dissociations and causes the slow onset of the steroid inhibition.

There are two additional pharmacodynamic properties of steroid-induced NMDAR inhibition that are likely to be clinically relevant. First, the peak amplitude and the ratio of the steadystate/peak were not significantly changed for the first and the subsequent NMDAR response made in the presence of steroid. This indicates that, in contrast to the onset of inhibition, which requires NMDAR activation, steroid dissociation proceeds at the same rate independently of receptor activation (Petrovic et al., 2005). This foot-in-the-door mechanism of inhibition (Sobolevskii and Khodorov, 2002; Vyklicky et al., 2014, 2015) is critical for the ability of steroids to inhibit steady-state responses while leaving the peak relatively intact. In contrast, trapping blockers such as memantine cannot dissociate from the receptor in the absence of the agonist, progressively inhibiting peak responses more strongly with repeated receptor activation. The second useful property of steroid-induced NMDAR inhibition is its voltage independence (Petrovic et al., 2005), which ensures that steroids would remain effective even in pathologically depolarized cells. In contrast, NMDAR inhibition by memantine becomes weaker at depolarized potentials (Chen et al., 1992).

\section{Steroid modulation of synaptic transmission}

We show that steroids (PA-S and PA-hPim) have multiple effects on synaptic transmission. Consistent with the results obtained on recombinant receptors, the postsynaptic effects were characterized by a lower degree of inhibition of NMDAR EPSCs than of tonic NMDA currents, with no postsynaptic effect on the AMPA EPSC. The decrease in the paired-pulse ratio and the increase in the frequency of AMPA mEPSC are consistent with a presynaptic 
increase in the probability of glutamate release by PA-S and its synthetic analogs. A similar presynaptic potentiation has been described in various preparations for pregnenolone sulfate, a positive NMDAR modulator (Meyer et al., 2002; Mameli et al., 2005; Zamudio-Bulcock and Valenzuela, 2011), but the cellular mechanisms of steroid presynaptic actions are not well understood. Interestingly, the presynaptic potentiation further amplifies the selectivity of NMDAR inhibitory steroids for tonically over synaptically activated NMDARs and may contribute to their lack of undesirable side effects. It is not clear how the presynaptic potentiation may influence steroid neuroprotective properties. The potentiation of synaptic glutamate release could contribute to extracellular glutamate accumulation under pathological conditions (Wroge et al., 2012) and thus reduce steroid neuroprotective potential. Conversely, synaptic NMDAR stimulation via the presynaptic mechanism, combined with the selective inhibition of tonic NMDAR signaling, may be particularly effective at shifting the balance of synaptic versus extrasynaptic NMDAR signaling toward promoting cell survival (Hardingham and Bading, 2010). Potential advantages or disadvantages of presynaptic modulation by steroids will thus be an important issue to address in future studies.

We find that the endogenous neurosteroid PA-S inhibits tonically activated native NMDARs with $\sim 3$-fold higher potency than synaptically activated NMDARs. This difference in potency is at least as good as that reported previously (Xia et al., 2010) for therapeutic doses of memantine, which was suggested to underlie the tolerability of this clinically approved drug in patients suffering from Alzheimer's disease. However, others (Emnett et al., 2013) show that, in the continuous presence of memantine, synaptic NMDAR responses to repeated stimulation become progressively more inhibited, eventually resulting in minimal memantine selectivity for tonically over synaptically activated receptors. Our own results are more in agreement with Emnett et al. (2013) and confirm that PA-S is more selective than memantine for tonically over synaptically activated NMDARs. Further, our data show that the synthetic PA-S analog PA-hPim with the highest selectivity for inhibiting tonically over phasically activated recombinant receptors does not inhibit synaptically activated native NMDARs at all and in fact slightly potentiates their responses. Steroids thus represent a very promising therapeutic agent for excitotoxicity associated with acute and chronic NMDAR overstimulation.

\section{Steroid neuroprotective action in vivo}

Application of drugs inhibiting the NMDAR often shows a protective effect on the behavioral consequences of excitatory damage. However, many such drugs are excluded from the search for potential human neuroprotectants due to their significant side effects ranging from sensory and motor disturbances to the induction of schizophrenia-like symptoms such as hyperlocomotion and cognitive deficit. In fact, acute administration of noncompetitive NMDAR antagonists, such as dizocilpine (MK801), to laboratory rodents is a commonly used and extensively validated animal model of schizophrenia (Young et al., 2010; Micale et al., 2013). Memantine appears to be well tolerated clinically, but in animal studies, the neuroprotective dose of $20 \mathrm{mg} / \mathrm{kg}$ memantine (Chen et al., 1992) does cause hyperlocomotion (Bubser et al., 1992) and even lower doses induce cognitive impairments (Dix et al., 2010). After systemic administration of PA-hPim at 2 doses $(1 \mathrm{mg} / \mathrm{kg}$ or $10 \mathrm{mg} / \mathrm{kg})$, we found no evidence of hyperlocomotion in the open field and no cognitive impairment in the passive avoidance task or in the spontaneous alt- ernation test in the Y-maze. In contrast, MK-801, which is neuroprotective in the dose range $0.1-1 \mathrm{mg} / \mathrm{kg}$ (McDonald et al., 1990 ), caused severe cognitive impairment at doses $\geq 0.1 \mathrm{mg} / \mathrm{kg}$ and induced hyperlocomotion at doses $\geq 0.2 \mathrm{mg} / \mathrm{kg}$. We evaluated the neuroprotective effect of PA-hPim $(1 \mathrm{mg} / \mathrm{kg})$ on spatial learning performance in rats with NMDA-induced bilateral lesion of the hippocampus, a model of excitotoxic neurodegeneration (Wang et al., 1991). The performance of NMDA-lesioned animals treated with PA-hPim was significantly better than the performance of animals with the NMDA lesion and no different from the performance of control animals. The neuroprotective effect of PA-hPim is consistent with several reports of neuroprotective properties of other neuroactive steroid derivatives such as preganolone hemisuccinate (Weaver et al., 1997; Lapchak, 2004, 2006), pregnanolone glutamate (Rambousek et al., 2011), or pregnanolone valinate (MacNevin et al., 2009).

In summary, we show that PA-S and its synthetic analogs inhibit tonically activated NMDARs with a higher potency than excitatory neurotransmission and that steroid neuroprotective activity in behavioral tests is devoid of psychomimetic side effects. Our results provide valuable insights into the influence of neurosteroids on neuronal function and emphasize their potential use in the development of novel therapeutics with neuroprotective action.

\section{References}

Ahlrichs R, Bar M, Haser M, Horn H, Kolmel C (1989) Electronic-structure calculations on workstation computers-the program system turbomole. Chemical Physics Letters 162:165-169. CrossRef

Baker NA, Sept D, Joseph S, Holst MJ, McCammon JA (2001) Electrostatics of nanosystems: application to microtubules and the ribosome. Proc Natl Acad Sci U S A 98:10037-10041. CrossRef Medline

Barratt E, Bronowska A, Vondrásek J, Cerný J, Bingham R, Phillips S, Homans SW (2006) Thermodynamic penalty arising from burial of a ligand polar group within a hydrophobic pocket of a protein receptor. J Mol Biol 362:994-1003. CrossRef Medline

Bayly CI, Cieplak P, Cornell WD, Kollman PA (1993) A well-behaved electrostatic potential based method using charge restraints for deriving atomic charges-the resp model. J Phys Chem 97:10269-10280. CrossRef

Beck C, Wollmuth LP, Seeburg PH, Sakmann B, Kuner T (1999) NMDAR channel segments forming the extracellular vestibule inferred from the accessibility of substituted cysteines. Neuron 22:559-570. CrossRef Medline

Blanpied TA, Boeckman FA, Aizenman E, Johnson JW (1997) Trapping channel block of NMDA-activated responses by amantadine and memantine. J Neurophysiol 77:309-323. Medline

Borovska J, Vyklicky V, Stastna E, Kapras V, Slavikova B, Horak M, Chodounska H, Vyklicky L Jr (2012) Access of inhibitory neurosteroids to the NMDA receptor. Br J Pharmacol 166:1069-1083. CrossRef Medline

Bubser M, Keseberg U, Notz PK, Schmidt WJ (1992) Differential behavioural and neurochemical effects of competitive and non-competitive NMDA receptor antagonists in rats. Eur J Pharmacol 229:75-82. CrossRef Medline

Burgalossi A, Jung S, Man KN, Nair R, Jockusch WJ, Wojcik SM, Brose N, Rhee JS (2012) Analysis of neurotransmitter release mechanisms by photolysis of caged $\mathrm{Ca} 2+$ in an autaptic neuron culture system. Nat Protoc 7:1351-1365. CrossRef Medline

Cavelier P, Hamann M, Rossi D, Mobbs P, Attwell D (2005) Tonic excitation and inhibition of neurons: ambient transmitter sources and computational consequences. Prog Biophys Mol Biol 87:3-16. CrossRef Medline

Chen HS, Pellegrini JW, Aggarwal SK, Lei SZ, Warach S, Jensen FE, Lipton SA (1992) Open-channel block of N-methyl-D-aspartate (NMDA) responses by memantine: therapeutic advantage against NMDA receptormediated neurotoxicity. J Neurosci 12:4427-4436. Medline

Choi DW (1987) Ionic dependence of glutamate neurotoxicity. J Neurosci 7:369-379. Medline

Choi DW, Rothman SM (1990) The role of glutamate neurotoxicity in hypoxic-ischemic neuronal death. Annu Rev Neurosci 13:171-182. CrossRef Medline 
Clements JD, Lester RA, Tong G, Jahr CE, Westbrook GL (1992) The time course of glutamate in the synaptic cleft. Science 258:1498-1501. CrossRef Medline

Dix S, Gilmour G, Potts S, Smith JW, Tricklebank M (2010) A withinsubject cognitive battery in the rat: differential effects of NMDA receptor antagonists. Psychopharmacology 212:227-242. CrossRef Medline

Emnett CM, Eisenman LN, Taylor AM, Izumi Y, Zorumski CF, Mennerick S (2013) Indistinguishable synaptic pharmacodynamics of the N-methylD-aspartate receptor channel blockers memantine and ketamine. Mol Pharmacol 84:935-947. CrossRef Medline

Faucher F, Cantin L, Luu-The V, Labrie F, Breton R (2008) The crystal structure of human Delta4-3-ketosteroid 5beta-reductase defines the functional role of the residues of the catalytic tetrad in the steroid double bond reduction mechanism. Biochemistry 47:8261-8270. CrossRef Medline

Grimme S, Antony J, Ehrlich S, Krieg H (2010) A consistent and accurate ab initio parametrization of density functional dispersion correction (DFT-D) for the 94 elements H-Pu. J Chem Phys 132:154104. CrossRef Medline

Hardingham GE, Bading H (2010) Synaptic versus extrasynaptic NMDA receptor signalling: implications for neurodegenerative disorders. Nat Rev Neurosci 11:682-696. CrossRef Medline

Hardingham GE, Fukunaga Y, Bading H (2002) Extrasynaptic NMDARs oppose synaptic NMDARs by triggering CREB shut-off and cell death pathways. Nat Neurosci 5:405-414. Medline

Herman MA, Jahr CE (2007) Extracellular glutamate concentration in hippocampal slice. J Neurosci 27:9736-9741. CrossRef Medline

Huganir RL, Nicoll RA (2013) AMPARs and synaptic plasticity: the last 25 years. Neuron 80:704-717. CrossRef Medline

Jurecka P, Cerný J, Hobza P, Salahub DR (2007) Density functional theory augmented with an empirical dispersion term. Interaction energies and geometries of 80 noncovalent complexes compared with ab initio quantum mechanics calculations. J Comput Chem 28:555-569. CrossRef Medline

Karakas E, Furukawa H (2014) Crystal structure of a heterotetrameric NMDA receptor ion channel. Science 344:992-997. CrossRef Medline

Klamt A, Schuurmann G (1993) Cosmo-a new approach to dielectric screening in solvents with explicit expressions for the screening energy and its gradient. J Chem Soc Perk T 2:799-805.

Krystal JH, Karper LP, Seibyl JP, Freeman GK, Delaney R, Bremner JD, Heninger GR, Bowers MB Jr, Charney DS (1994) Subanesthetic effects of the noncompetitive NMDA antagonist, ketamine, in humans: psychotomimetic, perceptual, cognitive, and neuroendocrine responses. Archives of General Psychiatry 51:199-214. CrossRef Medline

Kudova E, Chodounska H, Slavikova B, Budesinsky M, Nekardova M, Vyklicky V, Krausova B, Svehla P, Vyklicky L (2015) A new class of potent $\mathrm{N}$-methyl-D-aspartate receptor inhibitors: sulfated neuroactive steroids with lipophilic D-ring modifications. J Med Chem 58:59505966. CrossRef Medline

Kussius CL, Kaur N, Popescu GK (2009) Pregnanolone sulfate promotes desensitization of activated NMDA receptors. J Neurosci 29:6819-6827. CrossRef Medline

Lapchak PA (2004) The neuroactive steroid 3-alpha-ol-5-beta-pregnan-20one hemisuccinate, a selective NMDA receptor antagonist improves behavioral performance following spinal cord ischemia. Brain Res 997: 152-158. CrossRef Medline

Lapchak PA (2006) 3alpha-OL-5-beta-pregnan-20-one hemisuccinate, a steroidal low-affinity NMDA receptor antagonist improves clinical rating scores in a rabbit multiple infarct ischemia model: synergism with tissue plasminogen activator. Exp Neurol 197:531-537. CrossRef Medline

Lee CH, Lü W, Michel JC, Goehring A, Du J, Song X, Gouaux E (2014) NMDA receptor structures reveal subunit arrangement and pore architecture. Nature 511:191-197. CrossRef Medline

Léveillé F, El Gaamouch F, Gouix E, Lecocq M, Lobner D, Nicole O, Buisson A (2008) Neuronal viability is controlled by a functional relation between synaptic and extrasynaptic NMDA receptors. FASEB J 22:42584271. CrossRef Medline

Lipton SA (1993) Prospects for clinically tolerated NMDA antagonists: open-channel blockers and alternative redox states of nitric oxide. Trends Neurosci 16:527-532. CrossRef Medline

Lynch MA (2004) Long-term potentiation and memory. Physiol Rev 84: 87-136. CrossRef Medline
MacNevin CJ, Atif F, Sayeed I, Stein DG, Liotta DC (2009) Development and screening of water-soluble analogs of progesterone and allopregnanolone in models of brain injury. J Med Chem 52:6012-6023. CrossRef Medline

Mameli M, Carta M, Partridge LD, Valenzuela CF (2005) Neurosteroidinduced plasticity of immature synapses via retrograde modulation of presynaptic NMDA receptors. J Neurosci 25:2285-2294. CrossRef Medline

Manahan-Vaughan D, von Haebler D, Winter C, Juckel G, Heinemann U (2008) A single application of MK801 causes symptoms of acute psychosis, deficits in spatial memory, and impairment of synaptic plasticity in rats. Hippocampus 18:125-134. CrossRef Medline

McDonald JW, Silverstein FS, Cardona D, Hudson C, Chen R, Johnston MV (1990) Systemic administration of MK-801 protects against N-methylD-aspartate- and quisqualate-mediated neurotoxicity in perinatal rats. Neuroscience 36:589-599. CrossRef Medline

Meyer DA, Carta M, Partridge LD, Covey DF, Valenzuela CF (2002) Neurosteroids enhance spontaneous glutamate release in hippocampal neurons. J Biol Chem 277:28725-28732. CrossRef Medline

Micale V, Kucerova J, Sulcova A (2013) Leading compounds for the validation of animal models of psychopathology. Cell Tissue Res 354:309-330. CrossRef Medline

Mikulecká A, Subrt M, Stuchlík A, Kubová H (2014) Consequences of early postnatal benzodiazepines exposure in rats. I. Cognitive-like behavior. Front Behav Neurosci 8:101. Medline

Newcomer JW, Krystal JH (2001) NMDA receptor regulation of memory and behavior in humans. Hippocampus 11:529-542. Medline

Olney JW (1969) Brain lesions, obesity, and other disturbances in mice treated with monosodium glutamate. Science 164:719-721. CrossRef Medline

Papadia S, Soriano FX, Léveillé F, Martel MA, Dakin KA, Hansen HH, Kaindl A, Sifringer M, Fowler J, Stefovska V, McKenzie G, Craigon M, Corriveau R, Ghazal P, Horsburgh K, Yankner BA, Wyllie DJ, Ikonomidou C, Hardingham GE (2008) Synaptic NMDA receptor activity boosts intrinsic antioxidant defenses. Nat Neurosci 11:476-487. CrossRef Medline

Parada-Turska J, Turski WA (1990) Excitatory amino acid antagonists and memory: effect of drugs acting at N-methyl-D-aspartate receptors in learning and memory tasks. Neuropharmacology 29:1111-1116. CrossRef Medline

Parsons MP, Raymond LA (2014) Extrasynaptic NMDA receptor involvement in central nervous system disorders. Neuron 82:279-293. CrossRef Medline

Petralia RS (2012) Distribution of extrasynaptic NMDA receptors on neurons. ScientificWorldJournal 2012:267120. CrossRef Medline

Petrovic M, Sedlacek M, Horak M, Chodounska H, Vyklický L Jr (2005) 20-oxo-5beta-pregnan-3alpha-yl sulfate is a use-dependent NMDA receptor inhibitor. J Neurosci 25:8439-8450. CrossRef Medline

Pettersen EF, Goddard TD, Huang CC, Couch GS, Greenblatt DM, Meng EC, Ferrin TE (2004) UCSF Chimera-a visualization system for exploratory research and analysis. J Comput Chem 25:1605-1612. CrossRef Medline

Rambousek L, Bubenikova-Valesova V, Kacer P, Syslova K, Kenney J, Holubova K, Najmanova V, Zach P, Svoboda J, Stuchlík A, Chodounska H, Kapras V, Adamusova E, Borovska J, Vyklicky L, Vales K (2011) Cellular and behavioural effects of a new steroidal inhibitor of the N-methyl-Daspartate receptor 3alpha5beta-pregnanolone glutamate. Neuropharmacology 61:61-68. CrossRef Medline

Rogawski MA (1993) Therapeutic potential of excitatory amino acid antagonists: channel blockers and 2,3-benzodiazepines. Trends Pharmacol Sci 14:325-331. CrossRef Medline

Rogawski MA, Wenk GL (2003) The neuropharmacological basis for the use of memantine in the treatment of Alzheimer's disease. CNS Drug Rev 9:275-308. Medline

Sah P, Hestrin S, Nicoll RA (1989) Tonic activation of NMDA receptors by ambient glutamate enhances excitability of neurons. Science 246: 815-818. CrossRef Medline

Sali A, Blundell TL (1993) Comparative protein modelling by satisfaction of spatial restraints. J Mol Biol 234:779-815. CrossRef Medline

Salomon-Ferrer R, Case DA, Walker RC (2013) An overview of the Amber biomolecular simulation package. WIREs Comput Mol Sci 3:198-210. CrossRef

Sanner MF (1999) Python: a programming language for software integra- 
tion and development. Journal of molecular graphics and modelling 17: 57-61. Medline

Sobolevskii AI, Khodorov BI (2002) Blocker studies of the functional architecture of the NMDA receptor channel. Neurosci Behav Physiol 32: 157-171. CrossRef Medline

Sobolevsky AI, Beck C, Wollmuth LP (2002) Molecular rearrangements of the extracellular vestibule in NMDAR channels during gating. Neuron 33:75-85. CrossRef Medline

Sobolevsky AI, Rosconi MP, Gouaux E (2009) X-ray structure, symmetry and mechanism of an AMPA-subtype glutamate receptor. Nature 462: 745-756. CrossRef Medline

Stastna E, Chodounska H, Pouzar V, Kapras V, Borovska J, Cais O, Vyklicky L Jr (2009) Synthesis of C3, C5, and C7 pregnane derivatives and their effect on NMDA receptor responses in cultured rat hippocampal neurons. Steroids 74:256-263. CrossRef Medline

Traynelis SF, Wollmuth LP, McBain CJ, Menniti FS, Vance KM, Ogden KK, Hansen KB, Yuan H, Myers SJ, Dingledine R (2010) Glutamate receptor ion channels: structure, regulation, and function. Pharmacol Rev 62: 405-496. CrossRef Medline

Vyklicky V, Korinek M, Smejkalova T, Balik A, Krausova B, Kaniakova M, Lichnerova K, Cerný J, Krusek J, Dittert I, Horak M, Vyklicky L (2014) Structure, function, and pharmacology of NMDA receptor channels. Physiol Res 63:S191-S203. Medline

Vyklicky V, Krausova B, Cerný J, Balik A, Zapotocky M, Novotny M, Lichnerova K, Smejkalova T, Kaniakova M, Korinek M, Petrovic M, Kacer P, Horak M, Chodounska H, Vyklicky L (2015) Block of NMDA receptor channels by endogenous neurosteroids: implications for the agonist induced conformational states of the channel vestibule. Sci Rep 5:10935. CrossRef Medline

Wahl F, Obrenovitch TP, Hardy AM, Plotkine M, Boulu R, Symon L (1994) Extracellular glutamate during focal cerebral ischaemia in rats: time course and calcium dependency. J Neurochem 63:1003-1011. Medline

Wang S, Lees GJ, Rosengren LE, Karlsson JE, Stigbrand T, Hamberger A, Haglid KG (1991) The effect of an N-methyl-D-aspartate lesion in the hippocampus on glial and neuronal marker proteins. Brain Res 541: 334-341. CrossRef Medline

Weaver CE Jr, Marek P, Park-Chung M, Tam SW, Farb DH (1997) Neuroprotective activity of a new class of steroidal inhibitors of the N-methylD-aspartate receptor. Proc Natl Acad Sci U S A 94:10450-10454. CrossRef Medline

Wroge CM, Hogins J, Eisenman L, Mennerick S (2012) Synaptic NMDA receptors mediate hypoxic excitotoxic death. J Neurosci 32:6732-6742. CrossRef Medline

Xia P, Chen HS, Zhang D, Lipton SA (2010) Memantine preferentially blocks extrasynaptic over synaptic NMDA receptor currents in hippocampal autapses. J Neurosci 30:11246-11250. CrossRef Medline

Young JW, Zhou X, Geyer MA (2010) Animal models of schizophrenia. Curr Top Behav Neurosci 4:391-433. CrossRef Medline

Zamudio-Bulcock PA, Valenzuela CF (2011) Pregnenolone sulfate increases glutamate release at neonatal climbing fiber-to-Purkinje cell synapses. Neuroscience 175:24-36. CrossRef Medline 